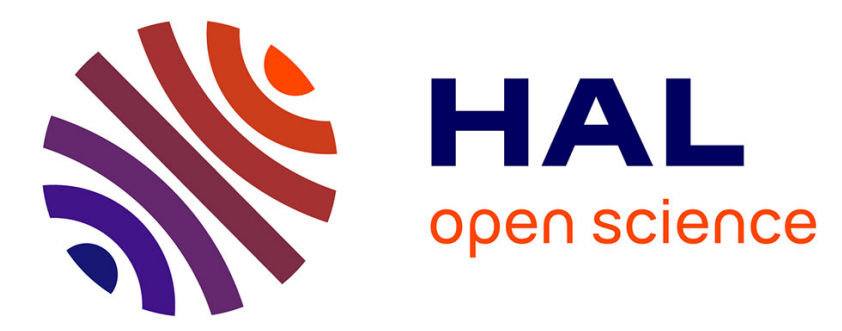

\title{
Review on the catalytic tri-reforming of methane - Part II: Catalyst development
}

\author{
Xuan-Huynh Pham, U.P.M. Ashik, Jun-Ichiro Hayashi, Alejandro Pérez \\ Alonso, Daniel Pla, Montserrat Gómez, Doan Pham Minh
}

\section{- To cite this version:}

Xuan-Huynh Pham, U.P.M. Ashik, Jun-Ichiro Hayashi, Alejandro Pérez Alonso, Daniel Pla, et al.. Review on the catalytic tri-reforming of methane - Part II: Catalyst development. Applied Catalysis A : General, 2021, 623, pp.1-17/118286. 10.1016/j.apcata.2021.118286 . hal-03287317

\section{HAL Id: hal-03287317 https://imt-mines-albi.hal.science/hal-03287317}

Submitted on 29 Jul 2021

HAL is a multi-disciplinary open access archive for the deposit and dissemination of scientific research documents, whether they are published or not. The documents may come from teaching and research institutions in France or abroad, or from public or private research centers.
L'archive ouverte pluridisciplinaire HAL, est destinée au dépôt et à la diffusion de documents scientifiques de niveau recherche, publiés ou non, émanant des établissements d'enseignement et de recherche français ou étrangers, des laboratoires publics ou privés. 


\title{
Review on the catalytic tri-reforming of methane - Part II: Catalyst development
}

\author{
Xuan-Huynh Pham ${ }^{\text {a }}$, U.P.M. Ashik ${ }^{\mathrm{b}}$, Jun-Ichiro Hayashi ${ }^{\mathrm{b}, \mathrm{c}}$, Alejandro Pérez Alonso ${ }^{\mathrm{a}, \mathrm{d}}$, \\ Daniel Pla ${ }^{\mathrm{d}}$, Montserrat Gómez ${ }^{\mathrm{d}}$, Doan Pham Minh ${ }^{\mathrm{a}, *}$ \\ ${ }^{a}$ Université de Toulouse, IMT Mines Albi, UMR CNRS 5302, Centre RAPSODEE, Campus Jarlard, F-81013 Albi Cedex 09, France \\ ${ }^{\mathrm{b}}$ Institute for Materials Chemistry and Engineering, Kyushu University, 6-1, Kasuga Koen, Kasuga 816-8580, Japan \\ ${ }^{\mathrm{c}}$ Transdisciplinary Research and Education Center of Green Technology, Kyushu University, Kasuga 816-8580, Japan \\ d Laboratoire Hétérochimie Fondamentale et Appliquée, UMR CNRS 5069, Université Toulouse 3 - Paul Sabatier, 118 route de Narbonne, 31062 , Toulouse Cedex 9, \\ France
}

Keywords:

Tri-reforming of methane

Active phase

Support

Catalyst promoter

Syngas

Catalyst design

\begin{abstract}
A B S T R A C T
Methane reforming allows the production of synthesis gas (syngas) which is an important gas mixture feedstock for the production of chemicals and energy carriers. Steam reforming of methane (SRM) and partial oxidation of methane (POM) have been deployed at large industrial scale, while dry reforming of methane (DRM) and more recently tri-reforming of methane (TRM) are intensively studied. TRM simultaneously combines SRM, POM and DRM in a unique process and allows overcoming several weaknesses of each individual methane reforming process: e.g. regulation of the molar ratio of $\mathrm{H}_{2} / \mathrm{CO}$ by controlling feed composition or adaptation to the variation in biogas composition as renewable resource. TRM process strongly requires a solid catalyst. To date, the design of efficient TRM catalysts remains a challenge. This work reviews recent achievements on the development of catalysts for TRM, and provides a guideline for future work related to TRM catalysts.
\end{abstract}

\section{Introduction}

Methane reforming makes possible the production of synthesis gas (syngas), which is an important gas mixture feedstock for various industrial sectors. Its annual production has continuously increased during the last decades [1,2]. Mostly, water, oxygen and carbon dioxide are used to reform methane according to the following equations:

Steam reforming of methane (SRM):

$\mathrm{CH}_{4}+\mathrm{H}_{2} \mathrm{O} \rightarrow \mathrm{CO}+3 \mathrm{H}_{2} \quad \Delta \mathrm{H}_{298}=+206 \mathrm{~kJ} / \mathrm{mol}$

Partial oxidation of methane (POM):

$\mathrm{CH}_{4}+1 / 2 \mathrm{O}_{2} \rightarrow \mathrm{CO}+2 \mathrm{H}_{2} \quad \Delta \mathrm{H}_{298}=-36 \mathrm{~kJ} / \mathrm{mol}$

Dry reforming of methane (DRM):

$\mathrm{CH}_{4}+\mathrm{CO}_{2} \rightarrow 2 \mathrm{CO}+2 \mathrm{H}_{2} \quad \Delta \mathrm{H}_{298}=+274 \mathrm{~kJ} / \mathrm{mol}$

SRM and DRM are strongly endothermic reactions, while POM is a slightly exothermic one. Generally, these reactions are favorable at high temperatures, and require a solid catalyst [3-8]. A common feature is related to the catalyst deactivation by coke deposition and/or by thermal sintering $[3-8,9]$. Thus far, SRM and POM are already deployed at the industrial scale for syngas production from natural gas [10-12], while DRM is still at a research and development stage. However, SRM is an energy-intensive process because of its high temperatures $\left(c a .900^{\circ} \mathrm{C}\right)$ to favor methane conversion, and high steam-to-methane ratio $(\mathrm{S} / \mathrm{C}=$ $3-4)$ to limit the catalyst deactivation by coke deposition $[10,13,14]$. Consequently, energy is lost during syngas cooling to the temperature of downstream processes (i.e. Fisher-Tropsch synthesis (FTS): $220-250{ }^{\circ} \mathrm{C}$; water-gas shift (WGS): $200-450{ }^{\circ} \mathrm{C}$, etc.) $[15,16]$. For POM, several drawbacks can be involved (i) catalyst bed hot-spots; (ii) high cost of syngas purification to remove residual $\mathrm{O}_{2}$; (iii) catalyst deactivation by re-oxidation of metallic nanoparticles, and coke deposition; iv) fire hazard of $\mathrm{O}_{2}$ and oxygen-enriched mixtures; etc. [17]. For DRM, despite a consequent effort devoted to this reaction during the last decades, the development of an economically viable solid catalyst, which resists to carbon formation and thermal sintering, is still a crucial challenge for a future commercialization [18].

Tri-reforming of methane (TRM) combines SRM, POM and DRM in a unique process (Eq. 4) [19]. TRM exhibits several advantages compared

\footnotetext{
* Corresponding author.

E-mail address: doan.phamminh@mines-albi.fr (D. Pham Minh).
} 
to each individual SRM, POM or DRM process, including: limitation of coke formation by steam; heat consumption reduction by POM exothermic reaction; and $\mathrm{CO}_{2}$ valorization into syngas. Especially, TRM not only offers the possibility of controlling the molar ratio of $\mathrm{H}_{2}$ /CO by adjusting the feed composition (Eq. 4), which is not the case of the individual SRM, POM or DRM, but also it is particularly adapted for syngas production from renewable resources such as biogas and/or landfill gas, which contain mixtures of $\mathrm{CO}_{2}, \mathrm{H}_{2} \mathrm{O}$ and $\mathrm{O}_{2}$ together with $\mathrm{CH}_{4}$ [20]. This means that biogas and/or landfill gas reforming does not need a specific separation step to perform syngas production via TRM. Moreover, flue gas from waste incinerators, which mainly contains $\mathrm{CO}_{2}, \mathrm{H}_{2} \mathrm{O}$ and $\mathrm{O}_{2}$, can also be used to reform methane via TRM [21]. In addition, according to Świrk et al. [22,23], TRM can be applied not only to reduce greenhouse gas emissions, but also to store energy under the form of chemical energy vectors. As for SRM, POM and DRM reactions, a solid catalyst is required to enable TRM at high temperatures $\left(>700^{\circ} \mathrm{C}\right)[3,4,24]$. Under such severe conditions, the design of highly-efficient TRM catalysts represents the crucial challenge in the frame of environmentally sustainable chemical industries [25-30].

$\mathrm{aCH}_{4}+\mathrm{bH}_{2} \mathrm{O}+\mathrm{cO}_{2}+\mathrm{dCO}_{2} \rightarrow \mathrm{eCO}+\mathrm{fH}_{2}$

Effort has been devoted to the development of TRM catalysts as evidenced by the growing number of articles published on TRM, which has quickly increased in recent years (Fig. 1). Thus, after the foremost work published by Song in 2001 [21], Moon [31] reviewed the reforming of gaseous hydrocarbons featuring a section on TRM (2008), while Soloviev et al. [4] reviewed the oxidative reforming of methane, including a discussion on the thermodynamics of TRM (2018). In 2019, Arab Aboosadi and Yadecoury [3] reviewed the impact of feed composition and reaction temperature in TRM. More recently, in 2020, Zhao et al. [32] reviewed biogas reforming, with a sub-section on TRM. It is also worth to mention that no work has been reported on TRM at large scale yet.

The present contribution belongs to a series of two review papers on TRM. The first one, entitled "Review on the catalytic tri-reforming of methane - Part I: impact of operating conditions, catalyst deactivation and regeneration" [33], has discussed the aspects of thermodynamic, mechanism, operating condition impact, and catalyst deactivation and regeneration. The second one (this work) provides a comprehensive overview on the rational design of TRM catalysts, including the following main sections: (i) active catalytic phases; (ii) catalyst supports; (iii) and catalyst promoters. To the best of our knowledge, this is the first review devoted to the rational design and development of TRM catalysts. Current challenges, outcomes and critical recommendations are also addressed.

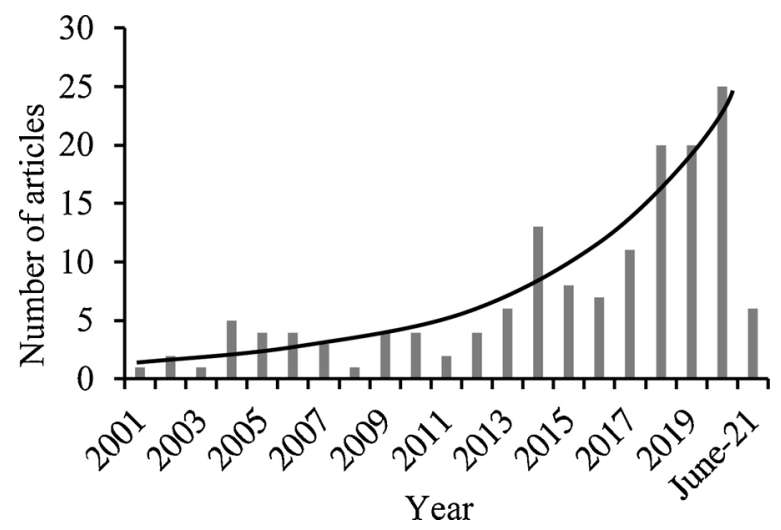

Fig. 1. Number of articles found on the Web of Science using "tri-reforming" and "methane" as keywords (data on June 21, 2021).

\section{Active catalytic phase}

As stated above, TRM allows producing syngas with a desired $\mathrm{H}_{2} / \mathrm{CO}$ ratio, but its study has only started since the early 2000s [34-36]. The TRM process needs a solid catalyst to get significant rates and yields at reasonable temperatures. However, the development of an active, selective, and stable catalyst is still a major challenge for TRM. The main criterion in the catalyst selection is its ability to catalyze the three reforming reactions (Eq. 1, Eq. 2, and Eq. 3). Likewise, coke deposition, and thermal catalyst sintering are main catalyst deactivation factors, along with the risk of catalyst re-oxidation by oxygen in the feed mixture $[29,30]$. Accordingly, catalysts used for SRM, POM and DRM are not suitable for TRM [19].

Nickel is generally considered as the active phase, immobilized on a solid support, e.g. $\mathrm{Al}_{2} \mathrm{O}_{3}, \mathrm{ZrO}_{2}, \mathrm{CeO}_{2}$, etc. Given that the structure and composition of the resulting catalytic material determine its performance [35], this section focuses on the correlation between catalyst preparation methods, both the nature of the active metal species as well as catalyst loadings, and the efficiency of the as-prepared catalytic materials towards TRM, taking into account their physicochemical characteristics. New trends in the engineering of the active phase in TRM will also be discussed (Scheme 1).

\subsection{Catalyst preparation methods}

To date, various approaches have been applied to synthesize catalysts for TRM, including hydrothermal process, combustion synthesis, microemulsion, co-precipitation, and impregnation.

\subsubsection{Impregnation}

Impregnation is commonly used in heterogeneous catalysis thanks to its practical ease, low cost, and low waste formation [37]. The dried impregnated materials are usually activated by calcination and/or reduction to obtain the required catalyst. Song and Pan [27] described the impregnation of $\mathrm{Ni}\left(\mathrm{NO}_{3}\right)_{2}$ on various supports such as $\mathrm{CeO}_{2}, \mathrm{ZrO}_{2}$, $\mathrm{MgO}$, and the mixed oxide of $\mathrm{Ce}$ and $\mathrm{Zr}$. Support was suspended in an aqueous solution of $\mathrm{Ni}(\mathrm{II})$ precursor under agitation for $1 \mathrm{~h}$, followed by drying, grounding into powder, calcination under air, and reduction under hydrogen. In a TRM reaction using a fixed-bed reactor (reaction conditions: $100 \mathrm{mg}$ of catalyst, $1 \mathrm{bar}, 700-850{ }^{\circ} \mathrm{C}$, feed composition of $\mathrm{CH}_{4}: \mathrm{CO}_{2}: \mathrm{H}_{2} \mathrm{O}: \mathrm{O}_{2}=1: 0.48: 0.54: 0.1$ with $\mathrm{CH}_{4}$ flow rate $=25 \mathrm{~mL} / \mathrm{min}$ ), the following performance trends were found for $\mathrm{CO}_{2}$ conversion: $\mathrm{Ni} / \mathrm{MgO}>\mathrm{Ni} / \mathrm{MgO} / \mathrm{CeZrO}_{\mathrm{x}}>\mathrm{Ni} / \mathrm{CeO}_{2} \sim \mathrm{Ni} / \mathrm{ZrO}_{2}>\mathrm{Ni} / \mathrm{CeZrO}_{\mathrm{x}}$. The highest catalytic efficiency of $\mathrm{Ni} / \mathrm{MgO}$ could be tentatively explained by the following reasons. First, $\mathrm{MgO}$ support had the highest specific surface area and the highest basicity $\left(\mathrm{MgO} \sim \mathrm{CeZrO}_{\mathrm{x}}>\mathrm{ZrO}_{2}>\mathrm{CeO}_{2}\right)$. High specific surface area generally favors metal dispersion. Second, $\mathrm{Ni} / \mathrm{MgO}$ showed enhanced $\mathrm{CO}_{2}$ adsorption in comparison to other catalysts prepared by the same impregnation method. Thus, $\mathrm{CO}_{2}$, which is more acidic than $\mathrm{O}_{2}$ and $\mathrm{H}_{2} \mathrm{O}$, can preferentially be adsorbed on the support surface and enhance $\mathrm{CH}_{4}$ reforming to produce syngas while promoting coke gasification [38,39]. This result evidences a strong effect of the support in the catalytic efficiency of the catalytic material [27]. For further details, the characteristics of various catalyst supports for TRM are presented in the section 3 of this review.

The efficiency of the catalyst is directly related to the size of active metals, so it is important to optimize the parameters of the synthesis of the targeted catalytic materials. Lino et al. [40] prepared $\mathrm{MgAl}_{2} \mathrm{O}_{4}$ support (denoted as MA) by co-precipitation method. Then, MA was modified by addition of $\mathrm{ZrO}_{2}$ and with $\mathrm{X}-\mathrm{ZrO}_{2}(\mathrm{X}=\mathrm{Ce}$, $\mathrm{La}, \mathrm{Y}$ or Sm with the molar ratio of $\mathrm{X}$ to $\mathrm{Zr}=0.25$, denoted as $\mathrm{XZr}$ phase) using incipient wetness impregnation (IWI). Finally, Ni/XZr/MA (10 wt.\% Ni) catalysts were prepared by IWI method, followed by air calcination at $750{ }^{\circ} \mathrm{C}$. The addition of $\mathrm{Ce}, \mathrm{La}, \mathrm{Sm}$, and $\mathrm{Y}$ as promoters together with $\mathrm{ZrO}_{2}(\mathrm{XZr}$ phase) facilitates the reduction of $\mathrm{NiO}$ to $\mathrm{Ni}(0)$ and shifts the temperature programmed reduction (TPR) peak to lower temperature. Among 


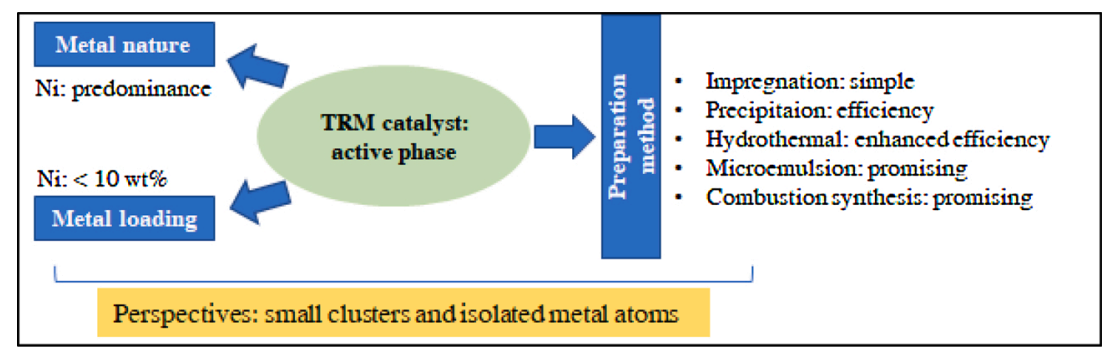

Scheme 1. Summary of the main parameters in consideration for the development of active phases for TRM catalysts.

the different promoters investigated, only CeZr led to a decrease of $\mathrm{Ni}$ particle size $(14 \mathrm{~nm})$ in comparison with the referent $\mathrm{Ni} / \mathrm{MA}$ catalyst (16 $\mathrm{nm}$ ). Obviously, in TRM reaction (reaction conditions: $750{ }^{\circ} \mathrm{C}, 85 \mathrm{mg}$ of catalyst, $\mathrm{CH}_{4}: \mathrm{CO}_{2}: \mathrm{H}_{2} \mathrm{O}: \mathrm{O}_{2}: \mathrm{N}_{2}=3: 1: 1.4: 0.5: 2$ molar ratio and $\mathrm{CH}_{4}$ flow rate $=51.5 \mathrm{~N} \mathrm{~mL} \mathrm{~min}^{-1}$ ), $\mathrm{Ni} / \mathrm{XZr} / \mathrm{MA}$ catalyst provided the highest $\mathrm{H}_{2}$ (68 \%) and CO (63\%) yields. Also, this catalyst showed the lowest rate of solid carbon formation, indicating the important role of the Ni particle size in methane reforming for syngas production and for coke resistance. Thus, by selecting a good promoter, the authors increased the $\mathrm{Ni}$ dispersion, improving consequently the catalyst efficiency.

In the section 2.5, the decrease of the Ni particle size to the level of isolated metal atoms is discussed together with its impact in the DRM reaction, one of the main reactions in TRM process. To the best of our knowledge, no work on isolated metal atoms in TRM has been reported in the open literature thus far.

Despite the technical simplicity of the impregnation process, this methodology provides limited control on the particle size of the active phase. This major drawback frequently renders the catalysts prepared by impregnation less efficient than those prepared by other methods, e.g. hydrothermal or precipitation methods [34].

\subsubsection{Precipitation}

Precipitation allows a good control of the particle size and catalyst structure. The surface characteristics, crystalline nature, metal-support interaction, and thereby catalytic performance can be tuned by changing the parameters of the synthesis. This was demonstrated by varying calcination temperatures, $\mathrm{pH}$ values, and reflux times in the synthesis of $\mathrm{Ni}-\mathrm{CaO}-\mathrm{ZrO}_{2}$ catalysts [41]. Nitrate salts of $\mathrm{Ni}(\mathrm{II}), \mathrm{Ca}(\mathrm{II})$ and $\mathrm{Zr}$ (IV) were co-precipitated at 8-14 $\mathrm{pH}$ range using a $\mathrm{NaOH}$ solution, and refluxed in deionized water for $1-10 \mathrm{~h}$. Different calcination temperatures of 500, 600 and $700{ }^{\circ} \mathrm{C}$ were applied. The authors found that the metal-support interaction (MSI) was enhanced at high calcination temperatures and high $\mathrm{pH}$ values, which provided stable catalysts for TRM. The reflux at relative short time was also crucial to increase the Ni dispersion within the $\mathrm{CaO}-\mathrm{ZrO}_{2}$ support. The optimal conditions for the catalyst preparation encompassed a $10-12 \mathrm{pH}$ treatment, $24 \mathrm{~h}$ of reflux, and further calcination at $700{ }^{\circ} \mathrm{C}$. The as-prepared catalytic materials enabled TRM (reaction conditions: $700{ }^{\circ} \mathrm{C}$, molar ratio of feed $\mathrm{CH}_{4}: \mathrm{CO}_{2}: \mathrm{O}_{2}: \mathrm{H}_{2} \mathrm{O}=$ 1:0.5:0.375:0.25, Gas Hourly Space Velocity (GHSV) $=34,000 \mathrm{~mL} \mathrm{~h}^{-1}$ $\mathrm{g}_{\text {cat }}^{-1}$ ) with up to $70 \%$ methane conversion [41].

Majewski and Wood [42] adopted the Stöber cum precipitation
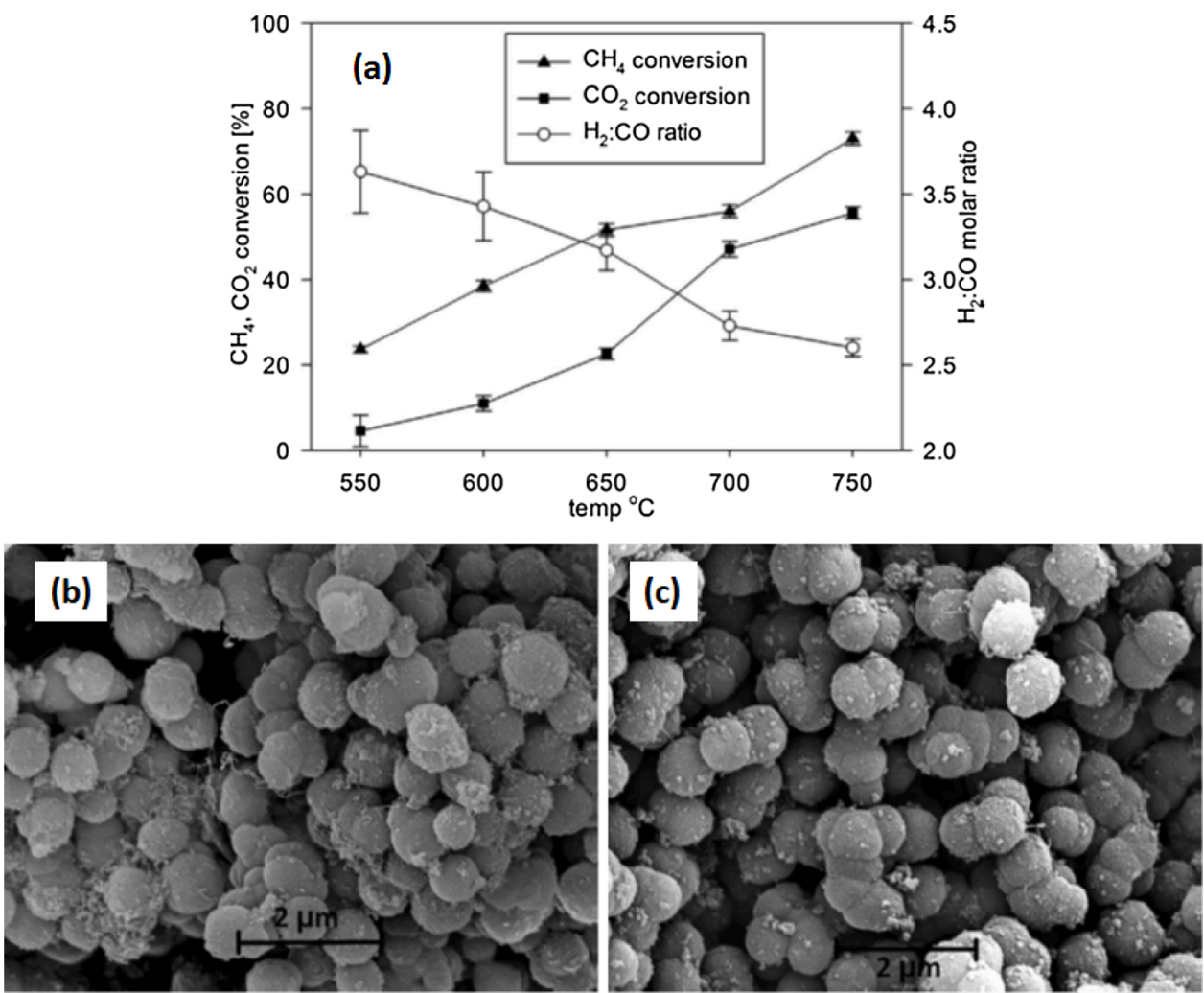

Fig. 2. a) Conversion of $\mathrm{CH}_{4}$ and $\mathrm{CO}_{2}$ (average value from $4 \mathrm{~h}$ reaction) over $\mathrm{Ni@SiO}$ catalyst at different temperatures. Reaction conditions: molar ratio of the feed $\mathrm{CH}_{4}: \mathrm{CO}_{2}: \mathrm{H}_{2} \mathrm{O}: \mathrm{O}_{2}: \mathrm{He}=1: 0.5: 0.5: 0.1: 0.4, \mathrm{CH}_{4}$ gas flow rate $25 \mathrm{~mL} \mathrm{~min}^{-1}, 0.2 \mathrm{~g}$ of catalyst. b) and c) Scanning Electron Microscopy (SEM) micrographs of the Ni@SiO${ }_{2}$ core@shell catalyst after $4 \mathrm{~h}$ reaction at b) $550{ }^{\circ} \mathrm{C}$, and c) $750{ }^{\circ} \mathrm{C}$. Reprinted with permission from [42], Copyright (2019) Elsevier. 
method to obtain a core@shell structured $\mathrm{Ni} / \mathrm{SiO}_{2}$ catalyst, in which silica spheres were covered by a Ni-film. The as-prepared 11 wt.\% $\mathrm{Ni@SiO}{ }_{2}$ catalyst exhibited enhanced catalytic properties (Fig. 2a). The catalyst produced whisker or carbon nanotubes at $550{ }^{\circ} \mathrm{C}$ in TRM, while such carbon accumulation was precluded at $750{ }^{\circ} \mathrm{C}$. However, particle cluster formation was slightly high at high temperature, as shown in Fig. 2 b and c.

Kumar and Pant [29] developed different Ni-based catalysts supported on hydrotalcite-derived $\mathrm{Mg}$-Al mixed oxide, with and without $\mathrm{Cu}$ or $\mathrm{Zn}$ acting as promoters, via the co-precipitation method. First, a $\mathrm{Ni}-\mathrm{Mg}$-Al catalyst was prepared by adding $\mathrm{Na}_{2} \mathrm{CO}_{3}$ to an aqueous solution of nitrates salts of $\mathrm{Ni}(\mathrm{II}), \mathrm{Mg}(\mathrm{II})$ and $\mathrm{Al}(\mathrm{III})$ at ambient conditions. Then, $\mathrm{Cu}$ doped Ni-Mg-Al (Ni-Cu-Mg-Al) and $\mathrm{Zn}$-doped Ni-Mg-AL (Ni-Zn-Mg-Al) catalysts were prepared by the same method using the appropriate nitrate salt $\mathrm{Cu}\left(\mathrm{NO}_{3}\right)_{2}$ and $\mathrm{Zn}\left(\mathrm{NO}_{3}\right)_{2}$. Additionally, two other $\mathrm{Ni}-\mathrm{Mg}$-Al catalysts were prepared by the "memory method". The latter is a sequential approach, which consisted of the co-precipitation of $\mathrm{Mg}-\mathrm{Al}$ support, followed by air calcination at 500 or $900{ }^{\circ} \mathrm{C}$. Then, Ni deposition on these supports was carried out to obtain Ni-Mg-Al_me@500 and Ni-Mg-Al_me@900 catalysts. As showed in Fig. 3, despite its highest specific surface area $\left(132 \mathrm{~m}^{2} \mathrm{~g}^{-1}\right)$ and its highest basic site density (107 $\mu \mathrm{mol} \mathrm{g}^{-1}$ ), the non-doped Ni-Mg-Al catalyst performed the lowest catalytic performance, due to its lowest degree reduction of $\mathrm{Ni}$ (only $47 \%$ ). Changing the catalyst preparation to the memory method improves $\mathrm{Ni}$
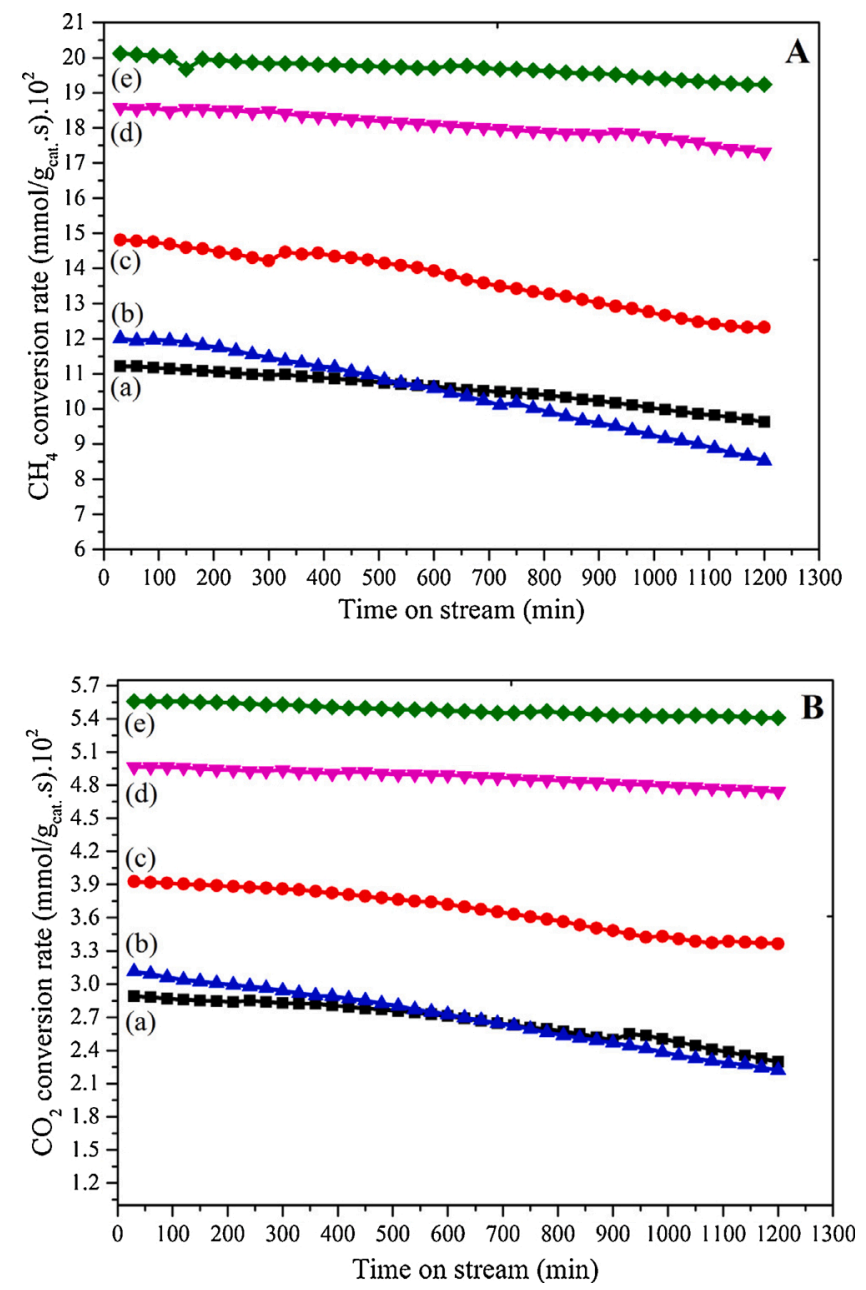

Fig. 3. Conversion rates of $\mathrm{CH}_{4}$ (A) and $\mathrm{CO}_{2}$ (B) in TRM over (a) Ni-Mg-Al; (b) Ni-Mg-Al_me@500, (c) Ni-Mg-Al_me@900, (d) Ni-Cu-Mg-Al and (e) Ni-Zn-MgAl. Reaction conditions: molar ratio of $\mathrm{CH}_{4}: \mathrm{CO}_{2}: \mathrm{H}_{2} \mathrm{O}: \mathrm{O}_{2}: \mathrm{N}_{2}=$ 1:0.23:0.46:0.07:0.28, GHSV $=49,200 \mathrm{~mL} \mathrm{~h}^{-1} \mathrm{~g}^{-1}, 800{ }^{\circ} \mathrm{C}, 1$ bar. Reprinted from [29], Copyright (2020), with permission from Elsevier. reduction degree (78\% with $\mathrm{Ni}-\mathrm{Mg}$-Al_me@900), and thus increases both $\mathrm{CH}_{4}$ and $\mathrm{CO}_{2}$ conversion rates. Thus, both doped catalysts exhibited higher catalytic activity and stability in comparison with non-doped catalysts. In the case of $\mathrm{Ni}-\mathrm{Cu}-\mathrm{Mg}$-Al catalyst, $\mathrm{Ni}-\mathrm{Cu}$ alloy was formed which reduced the size of $\mathrm{Ni}$ crystallites $(6.5 \mathrm{~nm}$ by XRD analysis, which is the smallest value among the five as-prepared catalysts) and occupied kink and edge Ni sites, explaining its high catalytic activity, due to the small $\mathrm{Ni}$ particles which favors reforming reactions. However, the characterization of the used $\mathrm{Ni}-\mathrm{Cu}-\mathrm{Mg}$-Al catalyst revealed a re-oxidation of Ni-Cu alloy, explaining a slight catalytic deactivation (Fig. 3). In the case of Ni-Zn-Mg-Al, Ni-Zn alloy was also formed but with a higher electron density on Ni, as observed by XPS in comparison with $\mathrm{Ni}-\mathrm{Cu}-\mathrm{Mg}$-Al catalyst. This fact explained the highest catalytic activity of Ni-Zn-Mg-Al catalyst. In addition, zinc-doped catalyst was not re-oxidized during TRM, in agreement with its good catalytic stability [29].

\subsubsection{Hydrothermal/solvothermal synthesis}

The hydrothermal treatment is an advanced catalyst synthesis methodology, which is generally carried out under controlled temperature and pressure conditions [43]. The solvothermal approach is similar to the hydrothermal one, but involving organic solvents instead of water [44]. A stainless-steel sealed autoclave is needed to withstand high pressure upon heating the solvent above its boiling point. This single-step high temperature-pressure procedure generally results in highly-crystalline materials. Key factors of this process include precursor concentration, solvent, stabilizing agent, reaction time, and temperature. Singha et al. [34] prepared $\mathrm{Ni} / \mathrm{ZrO}_{2}$ catalysts using cetyltrimethylammonium bromide, $\mathrm{Zr}(\mathrm{IV})$ propoxide, and $\mathrm{Ni}(\mathrm{II})$ nitrate hexahydrate as metal precursors under hydrothermal conditions $\left(180^{\circ} \mathrm{C}\right.$ for $24 \mathrm{~h}$ in a sealed autoclave, $\mathrm{pH} 12$ ), followed by filtration, drying at $100{ }^{\circ} \mathrm{C}$ for $12 \mathrm{~h}$ and air calcination at $600{ }^{\circ} \mathrm{C}$ for a further $6 \mathrm{~h}$. The resulting catalyst exhibited a uniform morphology with $54 \mathrm{~m}^{2} \mathrm{~g}^{-1}$ surface area, $10-40 \mathrm{~nm}$ Ni particle size. This catalyst had also a better $\mathrm{Ni}$-dispersion, and better MSI in comparison with a catalyst prepared by impregnation. Consequently, this as-prepared catalyst revealed superior performance in terms of conversion and $\mathrm{H}_{2} / \mathrm{CO}$ ratio at relative low reaction temperatures and gave improved energy efficiency, compared with other catalysts obtained via the impregnation method. Moreover, the impregnated catalyst rapidly deactivated, which was attributed to a surface area decline by a rapid particle agglomeration at high temperature. The authors claimed that both the poorly-dispersed $\mathrm{Ni}$ and the particle agglomeration in the impregnated catalyst favor reverse WGS reaction, thus reducing the $\mathrm{H}_{2} / \mathrm{CO}$ ratio [34].

Singha and co-workers [45] extended their investigation to Ni-MgO-CeO $-\mathrm{ZrO}_{2}$ composite nanoporous catalysts. They developed a new nanoporous $\mathrm{CeO}_{2}-\mathrm{ZrO}_{2}$ support by a straightforward solvothermal method. Ethanol solutions of zirconium isopropoxide, cerium nitrate and magnesium nitrate were mixed at $28{ }^{\circ} \mathrm{C}$ under stirring for $8 \mathrm{~h}$, followed by drying at $60^{\circ} \mathrm{C}$ and calcination at $400{ }^{\circ} \mathrm{C}$ for $5 \mathrm{~h}$. The formed $\mathrm{Ni}$ nanoclusters were deposited on the surface of these supports by the deposition-precipitation method using urea as precipitating agent. After studying a series of catalysts with different compositions and supports, they concluded that the observed catalytic performance can be explained by a combined contribution of multiple factors such as: specific surface area, particle size, metal dispersion, oxygen storage capacity, metal support interaction, and acidic/basic properties of the catalysts. In TRM reaction (reaction conditions: pressure (1 atm), 800 ${ }^{\circ} \mathrm{C}$, GHSV $=20,000 \mathrm{~mL} \mathrm{~g}^{-1} \mathrm{~h}^{-1}$, feed molar ratio $\mathrm{O}_{2}: \mathrm{CO}_{2}: \mathrm{H}_{2} \mathrm{O}: \mathrm{CH}_{4}: \mathrm{He}=$ $1: 1: 2.1: 5: 18$ ), they observed the highest performance by the $5 \mathrm{Ni}-\mathrm{Mg}$ CeZr catalyst, encompassing $95 \% \mathrm{CH}_{4}$ conversion with a $\mathrm{H}_{2}$ : $\mathrm{CO}$ molar ratio near to 2 , and enhanced catalytic stability during $100 \mathrm{~h}$ of reaction. This catalytic stability is basically attributed to the extended MSI, small $\mathrm{Ni}$ particle size (undetectable by XRD even at high Ni loading of $15 \mathrm{wt}$ $\%$ ), and the promoter effect of $\mathrm{Mg}$ to prevent coke formation. It is noteworthy to highlight that the solvothermal method employed 
provided the means to tune the characteristics of catalytic materials by adjusting the synthesis parameters [45].

In DRM, Das et al. [46] prepared surface-modified mesoporous alumina support by solvothermal approach using a mixture of ethanol and $\mathrm{HNO}_{3}$ acid as solvent mixture, aluminum isopropoxide as $\mathrm{Al}$ precursor, and cerium and magnesium nitrate salts as promoter precursors. A copolymer, poly(ethylene glycol)-block-poly(propylene glycol)block-poly(ethylene glycol), was also used as template to build the mesoporous structure of the support. The synthesis was carried out under soft conditions ( $28{ }^{\circ} \mathrm{C}$, stirring overnight), followed by an air calcination at $700{ }^{\circ} \mathrm{C}$ for $6 \mathrm{~h}$. The resulting mesoporous support favored the formation of well-dispersed and small Ni particles $(4-5 \mathrm{~nm})$ by nickel nitrate preparation using urea in an aqueous medium. After a reduction under $\mathrm{H}_{2}$ at $800{ }^{\circ} \mathrm{C}$, the catalysts showed a high catalytic activity ( $>90 \%$ of $\mathrm{CH}_{4}$ and $\mathrm{CO}_{2}$ conversion) in DRM at $800{ }^{\circ} \mathrm{C}$, feed composition $\mathrm{CH}_{4}: \mathrm{CO}_{2}: \mathrm{He}=1: 1: 8,34 \mathrm{~mL} \mathrm{~min}^{-1}$ gas flow rate; $0.2 \mathrm{~g}$ catalyst. The highest turnover frequency (TOF) reached $c a .1 .57$ and $1.40 \mathrm{~s}^{-1}$ for respectively $\mathrm{CH}_{4}$ and $\mathrm{CO}_{2}$ conversion. The prepared catalysts showed also a good stability at $700{ }^{\circ} \mathrm{C}$ during $c a .100 \mathrm{~h}$ of time-on-stream, thanks to a strong MSI, as revealed by TPR with reduction peaks above $450{ }^{\circ} \mathrm{C}$.

To sum up, hydrothermal/solvothermal methodology seems to be an adequate approach to prepare $\mathrm{Ni}$ supported catalysts with high $\mathrm{Ni}$ dispersion. However, to date, this methodology is scarcely applied for TRM process.

\subsubsection{Microemulsion}

Oil-in-water and water-in-oil represent the two of the most widely applied microemulsion-based synthetic routes [47]. Water, oil, surfactant, and a co-surfactant are the main components of a microemulsion system. The structural features of a catalyst can efficiently be controlled with this methodology, which renders more homogeneous metal particles size and distribution of the catalytic materials than the ones obtained by conventional approaches. However, this approach is seldom the one subsequently applied to TRM. Kim et al. [48] synthesized a multi-yolk-shell nanotube structured $\mathrm{NiCe} @ \mathrm{SiO}_{2}$ catalyst via a reverse microemulsion method. The Ni-Ce-yolk of the prepared catalyst was confined inside a $\mathrm{SiO}_{2}$ shell, leading to a remarkable metal-support interaction. TPR analyses confirmed that the multi-yolk-shell nanotube catalyst showed $c a$. 20 times higher hydrogen consumption. Catalysts with small yolk showed enhanced resistance to carbon deposition by instantaneous solid carbon oxidation. Furthermore, yolks larger than $30 \mathrm{~nm}$ exhibited stable activity at high oxidizer-methane feed ratio. Overall, the major advantage of the microemulsion method over conventional synthesis approaches is the convenient control of catalyst morphology and appropriate MSI [48].

Several works related to the synthesis of catalysts prepared by microemulsion for DRM reaction have been reported [49,50]. However, the work of Kim et al. is thus far the only one featuring the synthesis of TRM catalysts by microemulsion methods. Thus, more research is needed to better explore the potential of this synthesis methodology.

\subsubsection{Combustion synthesis}

This method was mostly applied by Pino's group for the preparation of different nickel containing catalysts towards TRM, such as $\mathrm{Ni} / \mathrm{CeO}_{2}$ [51,52], and $\mathrm{Ni} / \mathrm{CeO}_{2}$ doped with different amounts of $\mathrm{La}$ [53,54]. In this method, a mixture of $\left(\mathrm{NH}_{4}\right)_{2} \mathrm{Ce}\left(\mathrm{NO}_{3}\right)_{6}, \mathrm{Ni}\left(\mathrm{NO}_{3}\right)_{2} \cdot 6 \mathrm{H}_{2} \mathrm{O}$ and oxalyldihydrazide (fuel) was used. A precursor of promoter such as La $\left(\mathrm{NO}_{3}\right)_{2} \cdot 6 \mathrm{H}_{2} \mathrm{O}$ can also be added to the mixture. Then, the mixture was homogenized by ball milling with a minimum amount of water, before being introduced to a muffle furnace at $350{ }^{\circ} \mathrm{C}$ to give a flaming combustion. After the complete elimination of water, the mixture was ignited to burn with a flame leaving a solid sponge form. The latter is crushed prior to TRM experiments, yielding small Ni particles (ca. $9 \mathrm{~nm}$ [53]) on the surface of the support. The addition of La as promoter can not only decrease Ni particle size to $c a .3 \mathrm{~nm}$, but also increase the density of oxygen vacancy sites [53]. In TRM at $800{ }^{\circ} \mathrm{C}$ and 1 bar, these catalysts showed high methane conversion (up to ca. $96 \%$ [53]) and a good stability during a long time-on-stream of ca. $150 \mathrm{~h}$ [54].

To-date, the works of Pino's group discussed above seemed to be the first ones devoted to TRM. Taking into account the interesting results obtained, further investigation would be conducted on this synthesis way to explore its potential in catalyst development for TRM.

\subsubsection{Polymerized complex route}

This method was applied to the preparation of nickel-based perovskite-type $\mathrm{NdM}_{0.25} \mathrm{Ni}_{0.75} \mathrm{O}_{3}(\mathrm{M}=\mathrm{Cr}, \mathrm{Fe})$ catalysts for TRM [55]. First, a mixture of nitrate salts of metals is prepared in deionized water at desired molar ratio. Then, citric acid is added to this mixture at the molar ratio of citric acid / metals $=1.1 / 1$ for complexation of metal cations at $60{ }^{\circ} \mathrm{C}$ for $30 \mathrm{~min}$. After that, ethylene glycol is added and the temperature of the mixture is adjusted to $90{ }^{\circ} \mathrm{C}$ to perform the poly-esterification reaction, leading to the formation of a polymeric resin. After drying at $110^{\circ} \mathrm{C}$ for $16 \mathrm{~h}$, the resin is finally calcined at 500 ${ }^{\circ} \mathrm{C}$ for $30 \mathrm{~min}$, then $800{ }^{\circ} \mathrm{C}$ for $4 \mathrm{~h}$. This synthesis allowed obtaining catalysts having perovskite-like structure with the presence of nickel oxide particles, which can be reduced into metallic nickel under hydrogen. In TRM at $850^{\circ} \mathrm{C}$ and 1 bar, the prepared catalysts showed a relatively good catalytic performance with methane conversion in the range of $c a$. 55-70\% without notable catalyst deactivation during $14 \mathrm{~h}$ of time-on-stream. However, it is noticed that this catalyst structure requires much higher $\mathrm{Ni}$ content in comparison with $\mathrm{Ni}$-supported catalyst, without outstanding catalytic properties, which might be a weakness of this preparation method.

\subsubsection{Effect of catalyst preparation methods}

Catalyst synthesis method along with other preparation parameters (e.g. nickel precursor, calcination temperature, etc.) can impact parameters such as metal loading, metal particle size, metal dispersion, strength of MSI etc., and thus, the performance of a catalyst in TRM.

Singha et al. [34] examined the effect of catalyst synthesis method toward TRM activity (reaction conditions: $60 \mathrm{mg}$ of catalyst, molar ratio of $\mathrm{O}_{2}: \mathrm{CO}_{2}: \mathrm{H}_{2} \mathrm{O}: \mathrm{CH}_{4}: \mathrm{He}=1: 1: 2.1: 5: 18,500-800{ }^{\circ} \mathrm{C}$, reaction time $=6 \mathrm{~h}$, GHSV $=20,000-400,000 \mathrm{~mL} \mathrm{~g}^{-1} \mathrm{~h}^{-1}$ ). Using a hydrothermal approach, they prepared $\mathrm{ZrO}_{2}$ support (denoted as $\mathrm{ZrO}_{2}^{H T}$ ) and different $\mathrm{Ni} / \mathrm{ZrO}_{2}$ catalysts (denoted as $x \mathrm{Ni} / \mathrm{ZrO}_{2}^{H T}$, where $x$ means Ni loading equal to 2.3; 4.8 and $9.5 \mathrm{wt} \%$ ). By impregnation method, two catalysts containing 5 $\mathrm{wt} \% \mathrm{Ni}$ were prepared using $\mathrm{ZrO}_{2}^{H T}$ support (denoted as $5 \mathrm{NiZrO}_{2}^{\mathrm{Imp}}$ ) and a commercial $\mathrm{ZrO}_{2}$ support (denoted as $5 \mathrm{Ni} / \mathrm{ZrO}_{2}^{\mathrm{ImpCom}}$ ). These catalysts were investigated in TRM reaction at $500-800{ }^{\circ} \mathrm{C}$. As highlighted in Fig. 4 for three catalysts containing the similar Ni loading of $4.8-5 \mathrm{wt} \%$, the catalyst prepared by the hydrothermal method was much more active than those prepared by the impregnation method in the temperature range investigated [34]. The impregnated catalysts were inactive below $600{ }^{\circ} \mathrm{C}$, and despite their initial activity above $600{ }^{\circ} \mathrm{C}$, they rapidly deactivated due to the thermal sintering of Ni-containing phases. On the other hand, the catalyst prepared by a hydrothermal method exhibited high and stable catalytic performance with good selectivity towards syngas. Authors claimed that catalyst synthesis methods (and also the metal loading) can tune the surface and metal-support interaction features, hence directly influencing catalytic behavior. In fact, when hydrothermal method was adopted, the tetragonal $\mathrm{ZrO}_{2}$ with (111) plane was the major exposed surface for feed gases which may explain their improved catalytic performance compared to catalysts prepared by impregnation, where this phase was absent. Besides, the impregnation method resulted in large NiO crystallites, which was confirmed by highly intense and sharp NiO peak as evidenced by XRD, pointing to the presence of large particles and consequently a decrease of the specific surface area of the catalyst, together with a decrease in $\mathrm{Ni}$ dispersion [34]. In addition, compared to impregnation materials, the catalysts prepared by hydrothermal method had higher specific surface 

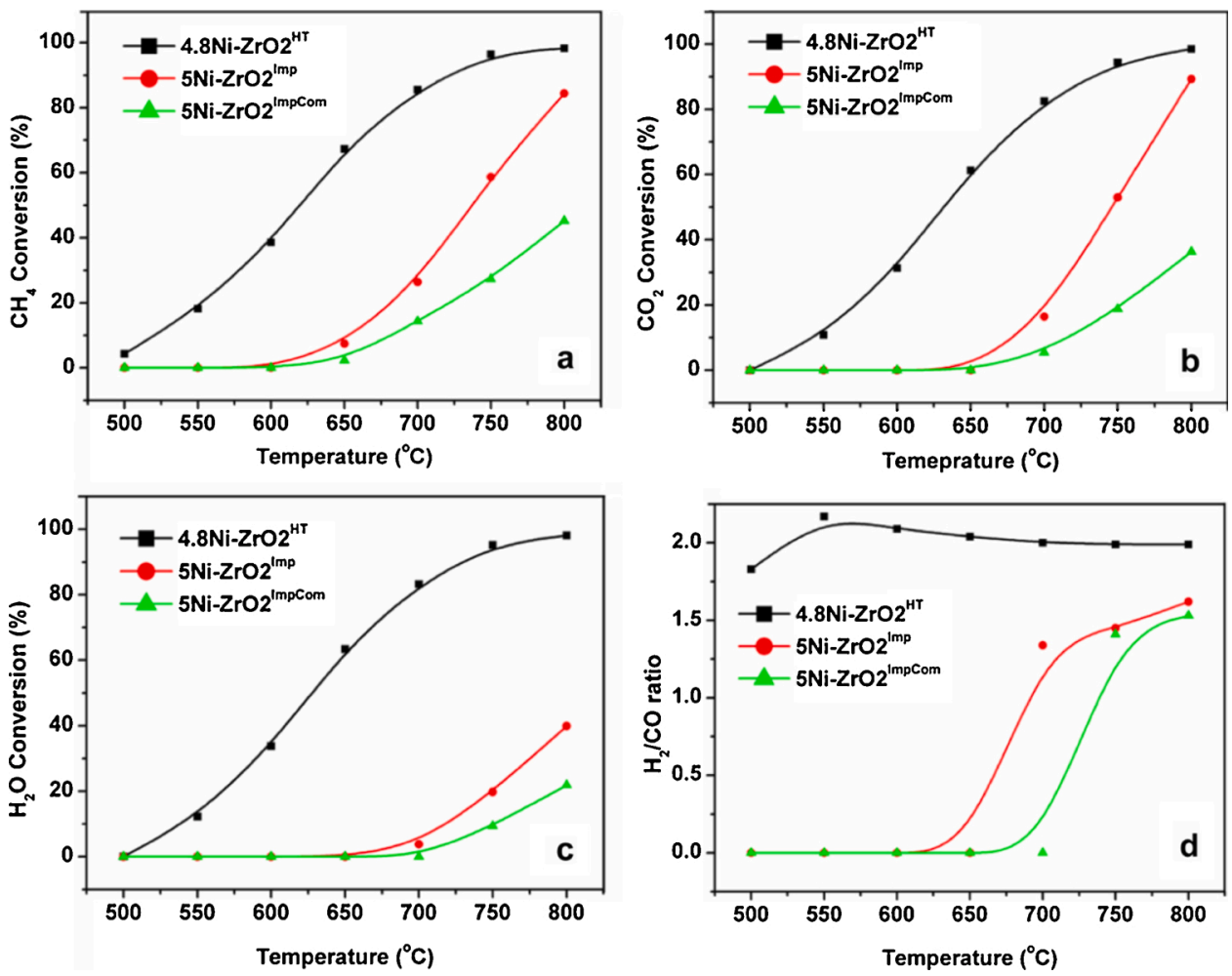

Fig. 4. Effect of catalyst preparation method on (a) $\mathrm{CH}_{4}$ conversion, (b) $\mathrm{CO}_{2}$ conversion, (c) $\mathrm{H}_{2} \mathrm{O}$ conversions and (d) $\mathrm{H}_{2} / \mathrm{CO}$ ratios. Reaction conditions: reaction time $=6 \mathrm{~h}$, temperature $=500-800{ }^{\circ} \mathrm{C}$, GHSV $=80,000 \mathrm{~mL} \mathrm{~g}^{-1} \mathrm{~h}^{-1}$, molar ratio of $\mathrm{O}_{2}: \mathrm{CO}_{2}: \mathrm{H}_{2} \mathrm{O}: \mathrm{CH}_{4}: \mathrm{He}=1: 1: 2 \cdot 1: 5: 18$ [34].

areas, and showed a better reducibility of $\mathrm{NiO}$ species, which contributed to their higher global catalytic efficiency in TRM reaction. Also, as shown in Table 1, Anchieta et al. [59] proved that a $5 \mathrm{wt} \% \mathrm{Ni} / \mathrm{ZrO}_{2}$ catalyst, prepared by impregnation method, exhibited lower catalytic performance (at the same reaction temperature and with a smaller GHSV) in comparison with $4.8 \mathrm{Ni} / \mathrm{ZrO}_{2}^{\mathrm{HT}}$ catalyst, prepared by hydrothermal method [34]. Similarly, $\mathrm{NiCe} / \mathrm{SiO}_{2}$ prepared by reverse microemulsion exhibited higher catalytic performance than the counterpart prepared by impregnation, despite the higher Ni dispersion of the latter (Table 1) [48]. This is explained by a controlled morphology (multi-yolk-shell nanotube) and synergetic interactions of $\mathrm{Ni}-\mathrm{Ce}$ and $\mathrm{Ni}-\mathrm{Si}$ species offered by the reverse microemulsion method. Combustion synthesis method also led to high performing TRM catalyst (Table 1) [53].

Walker et al. [35] investigated the effect of the synthesis method (wet impregnation and deposition precipitation) on the catalytic performance of $\mathrm{Ni}-\mathrm{MgO}-(\mathrm{Ce}, \mathrm{Zr}) \mathrm{O}_{2}$ catalysts in TRM. $\mathrm{CeO}_{2}-\mathrm{ZrO}_{2}$ supports (denoted as $(\mathrm{Ce}, \mathrm{Zr}) \mathrm{O}_{2}$ ) were first prepared by co-precipitation. Then, $\mathrm{Ni}$ and $\mathrm{Mg}$ loading on these supports were performed by wet impregnation and deposition-precipitation. The wet impregnation method enhanced the $\mathrm{Mg}$ loading compared to the deposition-precipitation approach. Consequently, the catalyst prepared by wet impregnation had higher $\mathrm{Mg}$

Table 1

Catalytic TRM Ni-ZrO $\mathrm{Zr}_{2}$ catalysts prepared by different methods; -: data not available; SSA: specific surface area.

\begin{tabular}{|c|c|c|c|c|c|c|c|c|c|c|c|}
\hline Catalyst & Preparation method & $\begin{array}{l}\text { SSA } \\
\left(\mathrm{m}^{2}\right. \\
\left.\mathrm{g}^{-1}\right) \\
\end{array}$ & $\begin{array}{l}\mathrm{Ni} \\
\text { dispersion } \\
(\%) \\
\end{array}$ & $\begin{array}{l}\text { Ni mean } \\
\text { particle size } \\
(\mathrm{nm})\end{array}$ & $\begin{array}{l}\text { Reaction } \mathrm{T} \\
\left({ }^{\circ} \mathrm{C}\right)\end{array}$ & $\begin{array}{l}\text { GHSV } \\
\left(\mathrm{mL} \mathrm{g} \mathrm{g}^{-1}\right. \\
\left.\mathrm{h}^{-1}\right)\end{array}$ & $\begin{array}{l}\mathrm{CH}_{4} \\
\text { conv. } \\
(\%) \\
\end{array}$ & $\begin{array}{l}\mathrm{CO}_{2} \\
\text { conv. } \\
(\%) \\
\end{array}$ & $\begin{array}{l}\mathrm{H}_{2} \mathrm{O} \\
\text { conv. } \\
(\%) \\
\end{array}$ & $\begin{array}{l}\mathrm{H}_{2} / \mathrm{CO} \\
\text { molar } \\
\text { ratio }\end{array}$ & Ref. \\
\hline 2.3 wt. $\% \mathrm{Ni} / \mathrm{ZrO}_{2}^{\mathrm{HT}}$ & Hydrothermal & 45.5 & 18.8 & 5.87 & 800 & 80,000 & 98.3 & 93.1 & 94.5 & 1.99 & \\
\hline 9.5 wt. $\% \mathrm{Ni} / \mathrm{ZrO}_{2}^{\mathrm{HT}}$ & Hydrothermal & 52.3 & 14.6 & 8.89 & 800 & 80,000 & 98.4 & 97.7 & 97.6 & 1.98 & \\
\hline 4.8 wt. $\% \mathrm{Ni} / \mathrm{ZrO}_{2}^{\mathrm{HT}}$ & Hydrothermal & 54.0 & 18.2 & 6.23 & 800 & 80,000 & 98.5 & 98.1 & 98.6 & 1.99 & [34] \\
\hline 5 wt. $\% \mathrm{Ni} / \mathrm{ZrO}_{2}^{\operatorname{Imp}}$ & Impregnation & 10.2 & 3.7 & 26.45 & 800 & 80,000 & 84.4 & 89.3 & 39.9 & 1.62 & \\
\hline 5 wt. $\% \mathrm{Ni} / \mathrm{ZrO}_{2}^{\text {ImpCom }}$ & Impregnation & 7.9 & 2.7 & 33.24 & 800 & 80,000 & 45.2 & 36.3 & 21.9 & 1.53 & \\
\hline 5 wt. $\% \mathrm{Ni} / \mathrm{ZrO}_{2}$ & $\begin{array}{l}\text { Precipitation cum } \\
\text { wet impregnation }\end{array}$ & 17.0 & - & 14.5 & 800 & 45,000 & 78.0 & 40.0 & - & 1.20 & [59] \\
\hline $\begin{array}{l}\mathrm{NiCe} / \mathrm{SiO}_{2} \\
(\mathrm{Ni}: 7.2-8.2 \mathrm{wt} \%) \\
(\mathrm{Ce}: 4.6-5.3 \mathrm{wt} \%)\end{array}$ & Impregnation & 486.0 & 1.71 & 59.1 & 750 & 60,000 & 78 & 72 & - & 1.7 & [48] \\
\hline $\begin{array}{l}\mathrm{NiCe} / \mathrm{SiO}_{2} \text {-multi- } \\
\text { yolk-shell } \\
\text { (Ni: } 7.2-8.2 \mathrm{wt} \%) \\
\text { (Ce: } 4.6-5.3 \text { wt } \%)\end{array}$ & $\begin{array}{l}\text { Reverse } \\
\text { microemulsion }\end{array}$ & 400.3 & 0.31 & 327.3 & 750 & 60,000 & 79 & 75 & - & 1.7 & [48] \\
\hline 5 wt. $\% \mathrm{Ni} / \mathrm{La}-\mathrm{CeO}_{2}$ & $\begin{array}{l}\text { Combustion } \\
\text { synthesis }\end{array}$ & - & - & - & 800 & 30,000 & 96.0 & 86.5 & - & 1.7 & [53] \\
\hline 5 wt. $\% \mathrm{Ni} / \mathrm{CeO}_{2}$ & $\begin{array}{l}\text { Combustion } \\
\text { synthesis }\end{array}$ & - & - & - & 800 & 30,000 & 93.0 & 83.0 & - & 1.7 & [53] \\
\hline
\end{tabular}


loading, which in turn improved the basicity of the catalyst, increased $\mathrm{CO}_{2}$ adsorption on the surface catalyst, and favored $\mathrm{CO}_{2}$ conversion.

In addition to the synthesis methodology, tuning parameters (e.g. nickel precursor, calcination temperature, etc.) can improve catalyst performance. García-Vargas et al. [56] compared $\mathrm{Ni} / \mathrm{CeO}_{2}$ and $\mathrm{Ni} / \mathrm{SiC}$ catalysts prepared from different nickel salts (nitrate, acetate, chloride and citrate) by impregnation method. For both supports used, nickel chloride and nickel citrate precursors resulted in catalysts with larger $\mathrm{Ni}$ particles $\left(92-116 \mathrm{~nm}\right.$ on $\mathrm{CeO}_{2}, 70-71 \mathrm{~nm}$ on $\left.\mathrm{SiO}_{2}\right)$, in comparison with the catalyst prepared from nickel nitrate and nickel acetate $(57-87 \mathrm{~nm}$ on $\mathrm{CeO}_{2}, 50-52 \mathrm{~nm}$ on $\mathrm{SiO}_{2}$ ), which in turn led to a lower catalytic behavior in TRM. For a given nickel precursor, the catalysts prepared with $\mathrm{SiC}$ support were more active and more stable than the counterparts prepared with $\mathrm{CeO}_{2}$ support. This fact is explained by the nature of $\mathrm{SiC}$ support, resulting in smaller Ni particles and stronger MSI in comparison with the catalysts prepared with $\mathrm{CeO}_{2}$ support.

MSI is also a key parameter to control catalyst performance, and can be tuned by selecting an appropriate support and thermal pretreatment conditions during the catalyst preparation [41,57]. Kumar et al. [57] studied $\mathrm{Ni}$ catalysts supported on different supports $\left(\mathrm{TiO}_{2}, \mathrm{SBA}-15\right.$, $\mathrm{MgO}$, and $\mathrm{Al}_{2} \mathrm{O}_{3}$ ) applied in TRM. These catalysts were prepared by wet impregnation technique. After the impregnation step, the residual water was removed under vacuum and the resulting solid was dried at $110^{\circ} \mathrm{C}$ for $15 \mathrm{~h}$, and further calcined at $400-950^{\circ} \mathrm{C}$ for $5 \mathrm{~h}\left(10^{\circ} \mathrm{C} / \mathrm{min}\right)$. The calcination temperature induced a remarkable impact on MSI: relative low calcination temperature led to weak MSI, while high temperature gave stronger MSI. For instant, $\mathrm{Ni} / \mathrm{MgO} @ 400$ (calcined at 400 ${ }^{\circ} \mathrm{C}$ ) had weaker MSI than $\mathrm{Ni} / \mathrm{MgO} @ 850$ (calcined at $850{ }^{\circ} \mathrm{C}$ ), as revealed by TPR analyses. Consequently, most of $\mathrm{Ni}$ in $\mathrm{Ni} / \mathrm{MgO} @ 850$ was not reduced and thus inactive in TRM. On the other hand, most of $\mathrm{Ni}$ in $\mathrm{Ni} / \mathrm{MgO} @ 400$ could be reduced and was active in TRM. However, under the same TRM conditions $\left(\mathrm{CH}_{4}: \mathrm{CO}_{2}: \mathrm{H}_{2} \mathrm{O}: \mathrm{O}_{2}: \mathrm{N}_{2}=1: 0.23: 0.46: 0.07: 0.28\right.$, space velocity $\left.=17,220 \mathrm{~mL} \mathrm{~h}^{-1} \mathrm{~g}^{-1}, 800{ }^{\circ} \mathrm{C}, 1 \mathrm{bar}\right), \mathrm{Ni} / \mathrm{MgO} @ 400$ exhibited higher deactivation rate than $\mathrm{Ni} / \mathrm{MgO} @ 850$, despite its higher initial activity. This is partially due to $\mathrm{Ni}$ sintering. In the case of $\mathrm{Ni} / \mathrm{Al}_{2} \mathrm{O}_{3}, \mathrm{TPR}$ analyses showed the presence of several reduction peaks at ca. $270-900{ }^{\circ} \mathrm{C}$ for $\mathrm{Ni} / \mathrm{Al}_{2} \mathrm{O}_{3} @ 400$, corresponding to both weak and strong MSI; only one broad reduction peak around $750-900{ }^{\circ} \mathrm{C}$ for $\mathrm{Ni} / \mathrm{Al}_{2} \mathrm{O}_{3} @ 950$, corresponding to strong MSI. In both cases, high extent of $\mathrm{Ni}$ reduction was reached ( 89 and $82 \%$ for the catalysts calcined respectively at 400 and $\left.950{ }^{\circ} \mathrm{C}\right)$. In TRM reaction $\left(\mathrm{CH}_{4}: \mathrm{CO}_{2}: \mathrm{H}_{2} \mathrm{O}: \mathrm{O}_{2}: \mathrm{N}_{2}\right.$ $=1: 0.23: 0.46: 0.07: 0.28$, space velocity $=17,220 \mathrm{~mL} \mathrm{~h}^{-1} \mathrm{~g}^{-1}, 800{ }^{\circ} \mathrm{C}, 1$ bar), $\mathrm{Ni} / \mathrm{Al}_{2} \mathrm{O}_{3} @ 950$ was consequently more stable than $\mathrm{Ni} / \mathrm{Al}_{2} \mathrm{O}_{3} @ 400$, due to strong MSI in $\mathrm{Ni} / \mathrm{Al}_{2} \mathrm{O}_{3} @ 950$, which limited thermal sintering. Surprisingly, $\mathrm{Ni} / \mathrm{Al}_{2} \mathrm{O}_{3} @ 950$ was also much more active than $\mathrm{Ni} / \mathrm{Al}_{2} \mathrm{O}_{3} @ 400$. This result is explained by the formation of monodispersed $\mathrm{Ni}$ atom at high calcination temperature. Therefore, it seems that strong MSI is required to limit or prevent thermal sintering but this parameter must be controlled together with other properties such as Ni reducibility and dispersion, which depend on the nature of each support (for a detailed discussion on the nature of supports, see Section 3).

\subsubsection{Conclusions}

To sum up, this section summarizes in a critical way the different methodologies for the synthesis of catalysts applied in TRM process reported to date. The impregnation method is the simplest way and can be used for a given adequate support (see Section 3). Hydrothermal treatment and precipitation methods both provide the means to effectively tailor the catalyst surface properties to enhance TRM efficiencies. It is worth to note that the hydrothermal treatment can provide highlycrystalline materials, despite its lower yields in comparison to precipitation approaches [43]. Hitherto, the microemulsion method and combustion synthesis are rarely implemented in TRM research, despite the promising initial results reported in the literature, and thus merit to be explored in future work.

\subsection{Effects of the nature of the active phase}

The commonly used catalyst for TRM reaction is that constituted of zero-valent nickel particles supported on different types of supports. The catalytic characteristics of d- and f-block elements in SRM, POM and DRM are well-known $[5,58]$. Hence, researchers are very watchful when deciding the active phase for TRM purposes as the risk of re-oxidation of low valent catalysts by oxygen in the feed stream is a major concern [30]. To the best of our knowledge, a comparative assessment of the catalytic performance of different metal-based catalysts has not yet been reported. Table 2 compares the activity, selectivity, and stability of the active phase studied in the literature for TRM. A full compilation of results on Ni-based catalysts in TRM is provided in the Supplementary Information (SI. 1).

Kozonoe et al. [30] studied Fe-based catalyst for TRM using multi-walled carbon nanotubes (MWCNT) as catalyst support. Fe deposition ( $5 \mathrm{wt} \%$ ) inside the pores of MWCNT support was performed by impregnating this support with a solution of iron nitrate in ethanol/water, followed by drying at $50{ }^{\circ} \mathrm{C}$ for $16 \mathrm{~h}$, air calcination at $350{ }^{\circ} \mathrm{C}$ for $2 \mathrm{~h}$ and $\mathrm{H}_{2}$ reduction at $400{ }^{\circ} \mathrm{C}$ for $2 \mathrm{~h}$. Then, $\mathrm{Co}$ and/or Cu deposition ( 5 wt\%) outside of the above Fe@MWCNT material by the similar impregnation approach in order to obtain Fe@MWCNT/Co, Fe@MWCNT/Cu, and Fe@MWCNT/CoCu catalysts. The Fe@MWCNT/Cu catalyst exhibited the highest methane conversion (62 $\%$, Table 2), explained by the highest metal reduction degree of this catalyst (98\%) in comparison with that of Fe@MWCNT/Co (53\%) and Fe@MWCNT/CoCu (50 \%). Furthermore, the Fe@MWCNT/Cu catalyst had a very good catalytic stability, while the Fe@MWCNT/CoCu catalyst showed an initial catalytic deactivation. A remarkable difference in the $\mathrm{H}_{2} / \mathrm{CO}$ molar ratio was observed with the activity of Fe@MWCNT/Cu compared to that with Fe@MWCNT/CoCu (Table 2). The significant variation, up to a factor of 2 , was attributed to the influence of metal nature and feed composition. In all cases, the $\mathrm{H}_{2} / \mathrm{CO}$ molar ratio below 1 indicated the occurrence of water involved in side-reactions such as RWGS. It is worth to note that Fe@MWCNT/CuCo favors $\mathrm{C}-\mathrm{O}$ bond cleavage to produce dehydration products and hence resulting in low $\mathrm{CO}$ production.

After TRM experiments, the structure of the catalyst was completely modified. MWCNT was destroyed and only less than $15 \mathrm{wt} \%$ of carbon remained in the used catalyst, while new metal oxides were formed (e.g. $\alpha-\mathrm{Fe}_{2} \mathrm{O}_{3}, \gamma-\mathrm{Fe}_{2} \mathrm{O}_{3}, \mathrm{CuO}, \mathrm{Cu}_{2} \mathrm{O}$ and $\mathrm{Co}_{3} \mathrm{O}_{4}$ ). The $\mathrm{Fe}$ and $\mathrm{Cu}$ particles remained small in the used $\mathrm{Cu}$ or Co doped catalysts (Fig. 5). However, the morphology of the bimetallic Fe@MWCNT/CoCu catalyst changed and exhibited a heterogeneous surface with the presence of large particles.

Considering the data shown in Table 2, even though the reaction conditions are not identical, the performance of Ni-based catalysts is far superior to that observed for Fe-based catalysts. For example, while almost all Fe-based catalysts performed a $\mathrm{CH}_{4}$ conversion in 40-60\% range, the Ni-based catalysts led to higher $\mathrm{CH}_{4}$ conversion (up to $98 \%$ ). Especially, under TRM reaction conditions (fixed-bed down flow reactor: $60 \mathrm{mg}$ of catalyst, $1 \mathrm{~atm}, 800{ }^{\circ} \mathrm{C}$, feed composition of $\mathrm{O}_{2}: \mathrm{CO}_{2}$ : $\mathrm{H}_{2} \mathrm{O}: \mathrm{CH}_{4}: \mathrm{He}=1: 1: 2.1: 5: 18$ with $\mathrm{GHSV}=80,000 \mathrm{~mL} \mathrm{~g}^{-1} \mathrm{~h}^{-1}$ ), the Ni/ $\mathrm{ZrO}_{2}$ catalyst prepared by hydrothermal treatment did not exhibit deactivation for $100 \mathrm{~h}$, obtaining nearly full $\mathrm{CH}_{4}$ conversion [34]. This outstanding catalyst performance is explained by a high Ni dispersion $(18.2 \%$, with mean Ni particle size of $6.2 \mathrm{~nm}$ ) and a strong MSI (TPR peaks around 340 and $420{ }^{\circ} \mathrm{C}$ ) of this catalyst. In another work, the influence of the ionic liquid on the morphology, acido-basicity, and $\mathrm{Ni}$ dispersion was investigated on the catalytic performance of $\mathrm{Ni} / \mathrm{ZrO}_{2}$ [59]. The use of an ionic liquid during the catalyst preparation by impregnation reduced the number of strong acid sites of the support, which improved the catalyst efficiency in TRM.

As previously mentioned in [61], it is important to highlight that to date, only few works have been devoted to noble metal catalysts for TRM (see Supplementary Information (SI. 1)). 
Table 2

Comparison of the activity, selectivity, and stability of the catalytically-active phase studied in TRM.

\begin{tabular}{|c|c|c|c|c|c|c|c|c|c|c|}
\hline \multirow[b]{2}{*}{ Catalysts } & \multirow{2}{*}{$\begin{array}{l}\text { Specific surface } \\
\text { area }\left(\mathrm{m}^{2} \mathrm{~g}^{-1}\right)\end{array}$} & \multirow{2}{*}{$\begin{array}{l}\text { Degree of } \\
\text { reduction }(\%)\end{array}$} & \multirow{2}{*}{$\begin{array}{l}\text { GHSV }(\mathrm{mL} \\
\left.\mathrm{g}^{-1} \mathrm{~h}^{-1}\right)\end{array}$} & \multirow[b]{2}{*}{$\begin{array}{l}\mathrm{T} \\
\left({ }^{\circ} \mathrm{C}\right)\end{array}$} & \multirow{2}{*}{$\begin{array}{l}\text { Time on } \\
\text { stream }(\mathrm{h})\end{array}$} & \multicolumn{3}{|c|}{ Initial conversion } & \multirow{2}{*}{$\begin{array}{l}\mathrm{H}_{2} / \mathrm{CO} \\
\text { molar ratio }\end{array}$} & \multirow[b]{2}{*}{ Ref. } \\
\hline & & & & & & $\begin{array}{l}\mathrm{X}_{\mathrm{CH} 4} \\
(\%)\end{array}$ & $\begin{array}{l}\mathrm{X}_{\mathrm{CO} 2} \\
(\%)\end{array}$ & $\begin{array}{l}\mathrm{X}_{\mathrm{H} 2 \mathrm{O}} \\
(\%)\end{array}$ & & \\
\hline $\begin{array}{l}\text { Fe@MWCNT/Cu } \\
\text { Metal loadings: } 5 \text { wt } \% \text { Fe, } 5 \text { wt } \% \text { Cu }\end{array}$ & 139.3 & 98.0 & 60,000 & 800 & 27 & 62.0 & 38.8 & 69.0 & 0.3 & \\
\hline $\begin{array}{l}\text { Fe@MWCNT/Co } \\
\text { Metal loadings: } 5 \text { wt } \% \text { Fe, } 5 \text { wt } \% \text { Co }\end{array}$ & 23.5 & 53.0 & 63,000 & 800 & 27 & 46.0 & 36.0 & 35.0 & 0.5 & [30] \\
\hline $\begin{array}{l}\text { Fe@MWCNT/CuCo } \\
\text { Metal loadings: } 5 \text { wt } \% \text { Fe, } 5 \text { wt } \% \text { Cu } \\
\text { and Co }\end{array}$ & 23.5 & 50.0 & 60,000 & 800 & 27 & 44.2 & 35.7 & 65.6 & 0.7 & \\
\hline $\begin{array}{l}4.8 \text { wt. } \% \mathrm{Ni}-\mathrm{ZrO}_{2} \mathrm{HT} \\
\text { Metal loading: } 4.8 \mathrm{wt} \% \mathrm{Ni}\end{array}$ & 54.0 & 18.2 & 80,000 & 800 & 100 & 98.5 & 98.1 & 98.6 & 1.99 & [34] \\
\hline $\begin{array}{l}\mathrm{Ni}-\mathrm{ZrO}_{2} \text {-ionic liquid } \\
\text { Metal loading ( } 5.8 \mathrm{wt} \% \mathrm{Ni} \text { ) }\end{array}$ & 11.0 & 84.3 & 48,000 & 800 & 5 & 39.0 & 20.5 & - & 2.4 & [59] \\
\hline $\mathrm{Ni} / \mathrm{Ce}-\mathrm{Zr}-\mathrm{Al}_{2} \mathrm{O}_{3}$ & 151.0 (calcined) & 7.3 & $161.5 \mathrm{~h}^{-1}(*)$ & 800 & 8 & 98.0 & 41.0 & - & 2 & [60] \\
\hline $\begin{array}{l}\text { Fresh/calcined catalyst }(13.0 / 10.6 \\
\text { (Ni) } 3.0 / 2.7(\mathrm{Ce}) 4.0 / 3.6(\mathrm{Zr})\end{array}$ & 131.0 (reduced) & & & & & & & & & \\
\hline $\begin{array}{l}\mathrm{Ni} / \mathrm{CeZr} / \mathrm{MgAl}_{2} \mathrm{O}_{4} \\
\text { Metal loading (by EDS chemical } \\
\text { analysis): } 8 \mathrm{wt} \% \mathrm{Ni}\end{array}$ & 91.0 & 100.0 & - & 750 & 6 & 74.0 & 34.5 & - & 1.1 & [40] \\
\hline $\begin{array}{l}\mathrm{Ni} @ \mathrm{SiO}_{2} \\
\text { Metal loading: } 11 \text { wt\% Ni }\end{array}$ & 26.1 & - & - & 750 & 4 & 73.0 & 91.1 & - & 2 & [42] \\
\hline $\mathrm{Ni} /$ Zeolite L (cylindrical 30-60 nm) & 95.32 & - & $\begin{array}{l}\text { WHSV } \\
=161.5 \mathrm{~h}^{-1}\end{array}$ & 800 & 1.5 & 82.0 & 24.0 & - & 1.9 & \\
\hline Metal loading: $11.92 \mathrm{wt} \% \mathrm{Ni}$ & & & & & & & & & & [61] \\
\hline $\begin{array}{l}\text { Rh-Ni/zeolite L (cylindrical 30-60 } \\
\text { nm) } \\
\text { Metal loadings: } 1.09 \text { wt } \% \text { Rh and } \\
13.17 \text { wt } \% \mathrm{Ni}\end{array}$ & 64.12 & - & $\begin{array}{l}\text { WHSV } \\
=161.5 \mathrm{~h}^{-1}\end{array}$ & 800 & 1.5 & 97.0 & 34.0 & - & 1.6 & \\
\hline
\end{tabular}

(-: not mentioned; HT: hydrothermal method; MWCNT: multi-walled carbon nanotubes; *: weight hourly space velocity).

\subsection{Effects of metal loading}

Even though the active phase is required in TRM catalysis, its excess may result in the agglomeration to form giant particles that in combination with poor dispersion can even promote the reverse WGS reaction, thus lowering the $\mathrm{H}_{2} / \mathrm{CO}$ ratio. The number of accessible active sites, their size and reducibility are the major factors to control the activity and selectivity $[62,63]$. Generally, small metal particles favor methane reforming $[63,64]$. Hence, the optimization of the active phase is relevant. Singha et al. [34] synthesized $\mathrm{Ni} / \mathrm{ZrO}_{2}$ catalysts containing $2.3,4.8$ and $9.5 \mathrm{wt} \% \mathrm{Ni}$ by hydrothermal method using cetyltrimethylammonium bromide as a cationic surfactant affording catalysts which exhibit specific surface areas of $45.5,54.0$ and $52.3 \mathrm{~m}^{2} \mathrm{~g}^{-1}$, and average Ni particle sizes of $5.87,6.23$ and $8.89 \mathrm{~nm}$ for respectively 2.3 , 4.8 and $9.5 \mathrm{wt} \% \mathrm{Ni}$ loading. Thus, the increase of Ni loading led to the increase of the average Ni particle size and subsequently a decreased $\mathrm{H}_{2}$ selectivity in TRM reaction (Fig. 6), which is attributed to the favored RWGS over large Ni-particles. Among the prepared catalysts, the one having $4.8 \mathrm{wt} \% \mathrm{Ni}$ loading exhibited the highest catalyst performance in TRM reaction, explained by a high Ni dispersion and a strong MSI (see Section 2.2. for the effects of the nature of the active phase on TRM process).

Singha et al. [45] also investigated MgCeZr-supported Ni catalysts containing 2.5, 5 and $10 \mathrm{wt} \%$ of $\mathrm{Ni}$. The catalyst $5 \mathrm{wt} \% \mathrm{Ni} / \mathrm{MgCeZr}$ showed the best catalytic performance given its enhanced reducibility (in comparison with $10 \mathrm{wt} \% \mathrm{Ni} / \mathrm{MgCeZr}$ ) and its large availability of active sites (in comparison with $2 \mathrm{wt} \% \mathrm{Ni} / \mathrm{MgCeZr}$ ) [45]. Pino et al. [65] studied Ni-La- $\mathrm{CeO}_{2}$ catalysts containing $1.76,3.66,7.88$ and $10.25 \mathrm{wt} \%$ $\mathrm{Ni}$ in TRM (500 mg catalyst, $800{ }^{\circ} \mathrm{C}, 1 \mathrm{bar}, \mathrm{GHSV}=30,000 \mathrm{~h}^{-1}$, and molar ratio of $\left.\mathrm{CH}_{4}: \mathrm{CO}_{2}: \mathrm{H}_{2} \mathrm{O}: \mathrm{O}_{2}=1: 0.46: 0.46: 0.1\right)$. The catalysts having 1.76 and $3.66 \mathrm{wt} \% \mathrm{Ni}$ showed similar $\mathrm{CH}_{4}$ (ca. $98 \%$ ) and $\mathrm{CO}_{2}$ (ca. 85-87 $\%)$ conversions, which were higher than those obtained with the catalysts containing 7.88 and $10.25 \mathrm{wt} \% \mathrm{Ni}$. The authors explained this result by the low $\mathrm{Ni}$ dispersion at high Ni loading.

In addition to the role of the active phase, metals were also extensively studied as catalyst promoters in TRM. Ni/Zn-Mg-Al exhibited superior performance over other compared catalysts, and the reason was attributed to the promotion effect of $\mathrm{Zn}$ via electron transfer to enrich $\mathrm{Ni}$ (0) [29]. Various promoters were investigated in TRM for improving the stability and activity of the active phase (see Section 4).

\subsection{New trend in the engineering of the active phase in TRM}

Recently, advances in material science open a new frontier in heterogeneous catalysis, related to single atom catalysis $[66,67]$. In single atom catalysts (SAC), isolated metal atoms, singly-dispersed on a support, constitute the active phase. This specific structural feature allows maximizing the efficiency of metal atom utilization, along with providing uniform active sites [68]. First, in a SAC, all metal atoms can be exposed to reactants instead of being buried in nanoparticles or bulk metal. Second, this specific structure provides a low-coordination environment of metal centers, which promotes adsorption ability and enhances catalytic performance. Third, quantum size effects can be fostered since the confinement of electrons leads to a discrete energy level distribution and a distinctive HOMO-LUMO gap. Furthermore, chemical bonding effects and charge transfer between metal and supports and associated interfaces can be enhanced, which allows regulating MSI [66].

In methane reforming reactions, small metal particles play a crucial role [69], as reported by Tang et al. [70] pointing to $10 \mathrm{~nm}$ of mean diameter as a threshold of Ni nanoparticle size for the intrinsic carbon deposit limitation. Recently, Ni-based SACs have been applied in DRM [71-74]. Even being considered as thermodynamically-unstable because of high surface free energy [66] (Fig. 7), SAC demonstrated high catalytic activities and stability under DRM conditions [71,72,74]. Thus, Akri et al. [71] successfully prepared and tested atomically-dispersed Ni single atoms supported on Ce-doped hydroxyapatite catalysts (containing $0.5,1$ and 2 wt.\% of Ni) in DRM. SACs showed higher activity, stability and coke-resistance compared to conventional nanoparticle-based catalyst. Notably, SACs only activate the first $\mathrm{C}-\mathrm{H}$ bond in $\mathrm{CH}_{4}$ and do not promote methane cracking, explaining their excellent coke-resistance. Interesting results in DRM were also 

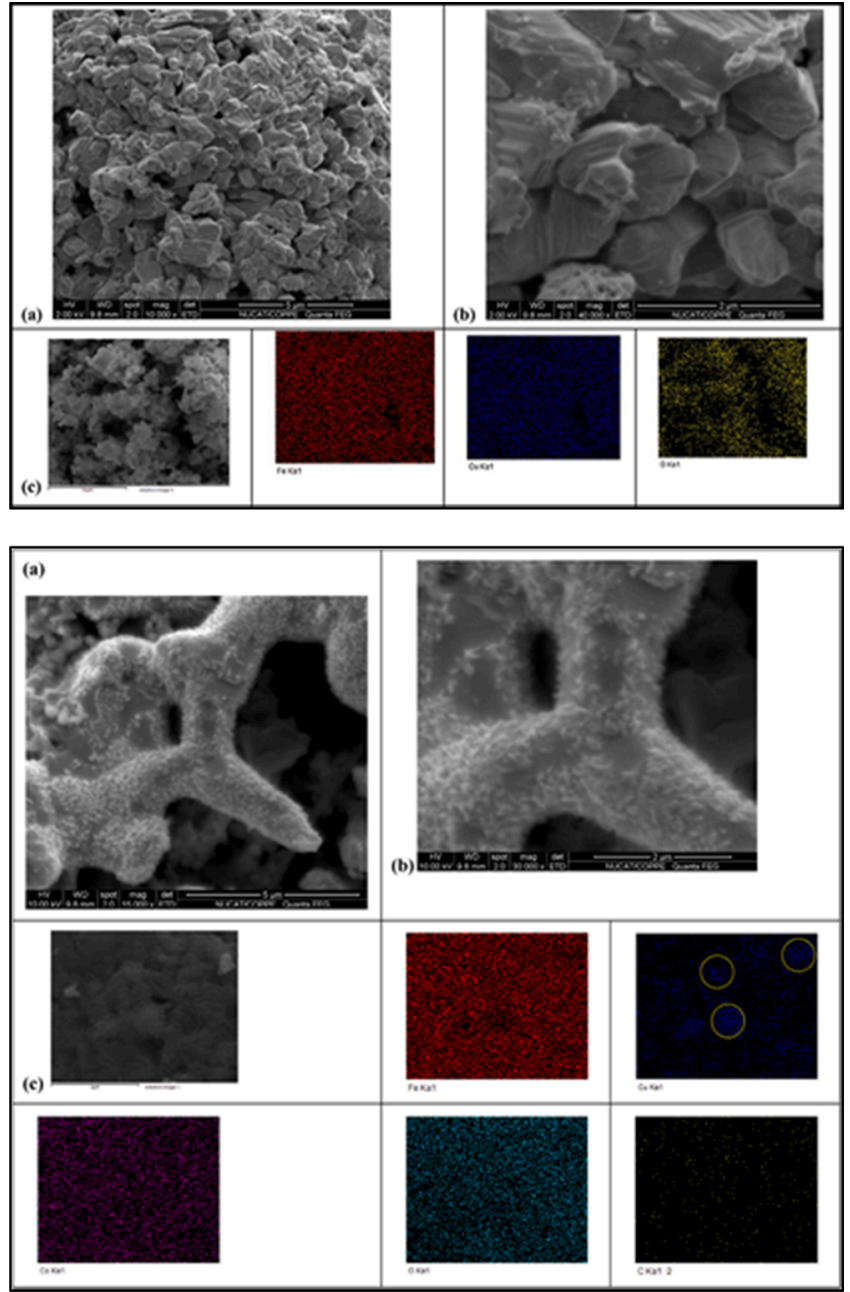

Fig. 5. SEM images of catalysts after TRM. Top: Fe@MWCNT/Cu - a) 10000x, b) 40000x, c) EDS mapping; Bottom: Fe@MWCNT/CoCu - a) 15000x, b) $30000 x$, c) EDS mapping. The monometallic catalyst maintained the small particle size, while the bimetallic catalyst led to agglomerates. Reprinted from [30], Copyright (2019), with permission from Elsevier.

obtained by Zuo et al. [72] using Ni/MgO SACs, and by Tang et al. [74] using $\mathrm{Ni} / \mathrm{CeO}_{2}, \mathrm{Ru} / \mathrm{CeO}_{2}$ and $\mathrm{Ni}-\mathrm{Ru} / \mathrm{CeO}_{2}$ SACs catalysts. High catalytic activity and stability of $\mathrm{Ni}-\mathrm{Ru} / \mathrm{CeO}_{2}$ SACs catalysts were attributed to the formation of isolated single atoms of $\mathrm{Ni}(0)$ and $\mathrm{Ru}(0)$. Nanoparticles were absent, even after DRM reaction at $600{ }^{\circ} \mathrm{C}$ (Fig. 8). The development of SACs will probably open new prospects for the design of highly-efficient heterogeneous catalysts applied in TRM. The combination of isolated atoms with small clusters $(<2 \mathrm{~nm})$, which can lead to "cooperative effects", as evidenced for other transformations (recently reviewed by Serp [75]) represents a strategy to be explored towards the development of TRM catalysts.

\section{Catalyst supports}

Supports play an important role in heterogeneous catalysis. In TRM, the following criteria are commonly required for an efficient catalyst support: (i) high thermal stability, (ii) high specific surface area for active phase dispersion, (iii) adequate MSI for metal reduction capacity and thermal sintering resistance, (iv) high basicity for adsorption of $\mathrm{CO}_{2}$ and coke limitation, (v) frequently presence of oxygen vacancies and high oxygen storage capacity for coke elimination, (vi) and affordable cost. As shown in SI. 1, various supports have been investigated in TRM, including: metal oxides, mixed oxides, zeolites, and silicon carbide.
Their performance is illustrated in Scheme 2 on the basis of different physico-chemical and thermal properties, and will be discussed hereafter.

\subsection{Alumina}

Alumina possesses several properties required for a convenient TRM catalyst support, such as high specific surface area, high thermal stability and low cost among others. In TRM, Ni/ $\mathrm{Al}_{2} \mathrm{O}_{3}$ catalysts have intensively been examined [19,28,76-79]. Solov'ev et al. [19] performed TRM using $\mathrm{Ni} / \mathrm{Al}_{2} \mathrm{O}_{3}$ catalysts prepared from structured cordierite with and without additives $\left(\mathrm{CeO}_{2}\right.$ and $\left.\mathrm{La}_{2} \mathrm{O}_{3}\right)$. Catalysts without additives showed low $\mathrm{CH}_{4}$ conversion (ca. 15-20\%) at 700-800 ${ }^{\circ} \mathrm{C}$ under various TRM conditions (molar ratio of $\mathrm{CH}_{4}: \mathrm{CO}_{2}: \mathrm{O}_{2}: \mathrm{H}_{2}: \mathrm{Ar}=$ 1:0.75:0.35:0.75:15; $\quad$ 1:0.65:0.3:0.75:16; $\quad$ 1:0.7:0.2:0.8:17; 1:0.9:0.25:0.75:15; 1:0.9:0.3:0.7:14; 1:0.55:0.2:1.0:16; WHSV $=12,000$ $\mathrm{h}^{-1}$ ) due to the re-oxidation of $\mathrm{Ni}(0)$ to $\mathrm{NiO}$. The addition of promoters overcame this problem, reaching up to $100 \%$ of methane conversion in the presence of $\mathrm{La}_{2} \mathrm{O}_{3}$ at $c a .650{ }^{\circ} \mathrm{C}$, and nearly $95 \%$ of methane conversion using $\mathrm{CeO}_{2}$ as additive at $c a .700{ }^{\circ} \mathrm{C}$.

By controlling the synthesis conditions of $\mathrm{Al}_{2} \mathrm{O}_{3}$ supports, Yoo et al. [80] evidenced the beneficial effect of high specific surface area and large pore volume in TRM reaction. $\mathrm{Ni} / \mathrm{Al}_{2} \mathrm{O}_{3}$, containing $20 \mathrm{wt} \% \mathrm{Ni}$ were prepared by sol-gel method, with or without a supercritical carbon dioxide drying step resulting respectively in mesoporous nickel-alumina aerogel catalyst (NAA) and mesoporous nickel-alumina xerogel catalyst (NAX). $\mathrm{CO}_{2}$ drying allowed increasing the specific surface area (370 and $320 \mathrm{~m}^{2} \mathrm{~g}^{-1}$ for NAA and NAX, respectively) and average pore size (12.7 and $7.2 \mathrm{~nm}$ for NAA and NAX, respectively). Consequently, NAA exhibited higher $\mathrm{CH}_{4}$ conversion and higher $\mathrm{H}_{2}$ yield than NAX, which correlated with the higher nickel dispersion of the former.

In the $\mathrm{Ni} / \mathrm{Al}_{2} \mathrm{O}_{3}$ catalyst described by Jiang et al. [81], three different Ni species can exist as evidenced by TRP analysis (Fig. 9): free NiO (peak at $c a .400{ }^{\circ} \mathrm{C}$ ); $\mathrm{NiO}$ interacting strongly with the support (peak at $c a .600$ ${ }^{\circ} \mathrm{C}$ ); and spinel $\mathrm{NiA}_{2} \mathrm{O}_{4}$ (peak at ca. $820{ }^{\circ} \mathrm{C}$ ), as evidenced by TPR. The reduction of the first two $\mathrm{Ni}$ species are generally possible under $\mathrm{H}_{2}$ resulting in the formation of zero-valent $\mathrm{Ni}$ which is active in methane reforming, albeit spinel $\mathrm{NiAl}_{2} \mathrm{O}_{4}$, usually formed at high calcination temperatures, is inactive in methane reforming [57,77,82], and its content can reach up to $90 \%$ of the nickel species [83]. Thus, even if the reduction of $\mathrm{NiAl}_{2} \mathrm{O}_{4}$ is difficult and requires harsh conditions (temperature $c a .800-900{ }^{\circ} \mathrm{C}$ ) $[57,81,85]$, it is strongly recommended to appropriately reduce it to $\mathrm{Ni}(0)$ in order to optimize the $\mathrm{Ni} / \mathrm{Al}_{2} \mathrm{O}_{3}$ catalyst performance $[28,57,83-85]$. Indeed, $\mathrm{NiAl}_{2} \mathrm{O}_{4}$ reduction results in well-dispersed Ni particles, which enhance the catalytic activity and limit carbon deposits [57,84,86,87].

\subsection{Silica}

Silica is generally a catalyst support of low cost, high thermal stability, and high specific surface area [42]. Different silica structures have been investigated to prepare ordered mesoporous silica supported nickel (Ni/SBA-15) [57,84,88], core-shell $\mathrm{Ni} / \mathrm{SiO}_{2}$ [42] and multi-yolk-shell $\mathrm{Ni} / \mathrm{SiO}_{2}$ (Fig. 10) [48]. Unlike $\mathrm{Ni} / \mathrm{Al}_{2} \mathrm{O}_{3}$ catalysts, no metal-support compound is formed and the catalytic performance mostly depends on silica morphology $[57,84]$.

$\mathrm{NiO}$ species can diffuse and remain confined inside silica pores, and their reduction needs high temperatures $\left(\mathrm{ca} .850^{\circ} \mathrm{C}\right)$, leading to small $\mathrm{Ni}$ (0) particles, which in turn, enhance catalytic activity. Also, NiO nanocrystallites located inside micropores need higher reduction temperatures than those occluded in mesopores [57,84]. Moreover, the confinement of Ni particles in the pores limits their thermal sintering in TRM [89]. Furthermore, these pores can serve as channels for reactants to diffuse through, while silica shell-structure can suppress carbon filament growth [48]. Notably, the direct contact between Ni clusters and unreduced or partially reduced $\mathrm{Ni}$ ions within the $\mathrm{SiO}_{2}$ matrix on the 
a
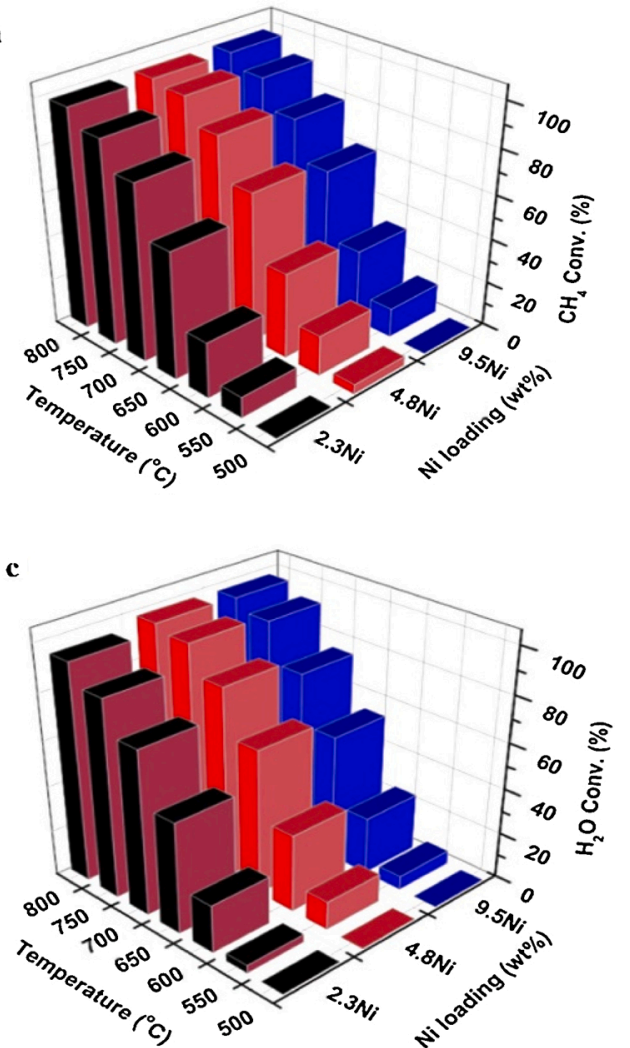

b
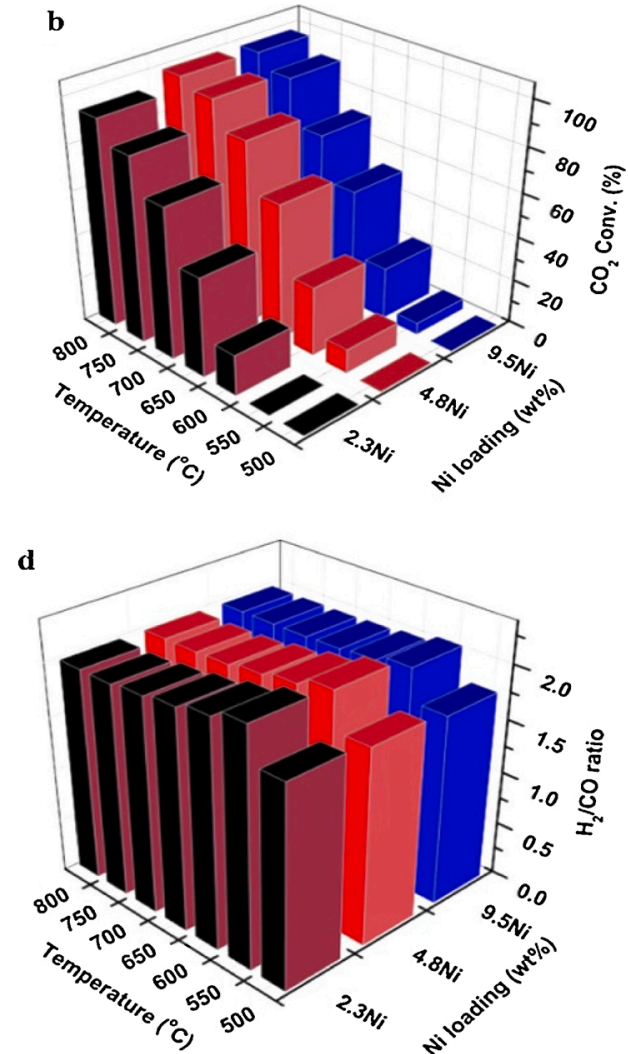

Fig. 6. Effect of $\mathrm{Ni}$ loading during TRM over $\mathrm{Ni}-\mathrm{ZrO}_{2}$ on (a) $\mathrm{CH}_{4}$ conversion, (b) $\mathrm{CO}_{2}$ conversion, (c) $\mathrm{H}_{2} \mathrm{O}$ conversion, and (d) $\mathrm{H}_{2} / \mathrm{CO}$ ratio. Reaction conditions: reaction time $=6 \mathrm{~h}$, temperature $=500-800{ }^{\circ} \mathrm{C}, \mathrm{GHSV}=80,000 \mathrm{~mL} \mathrm{~g}^{-1} \mathrm{~h}^{-1}$, molar ratio of $\mathrm{O}_{2}: \mathrm{CO}_{2}: \mathrm{H}_{2} \mathrm{O}: \mathrm{CH}_{4}: \mathrm{He}=1: 1: 2.1: 5: 18$. Reprinted from [34], Copyright (2016), with permission from Elsevier.

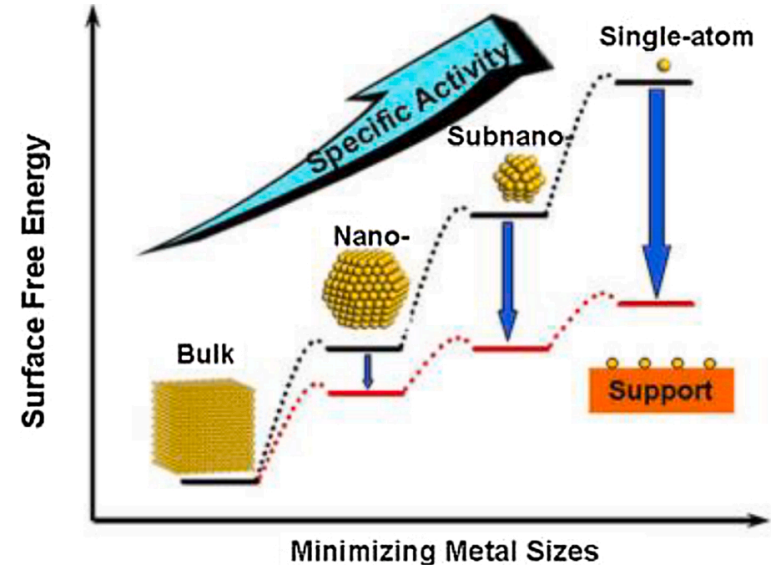

Fig. 7. Surface free energy and specific activity as a function of metal sizes. Reprinted with permission from [66]. Copyright (2013) American Chemical Society.

wall surface provides an anchoring effect and thus helps to prevent thermal sintering, as previously evidenced by Quek et al. [90]. Furthermore, the stabilization of Ni nanoparticles inside $\mathrm{SiO}_{2}$ nanotubes has also been recently reported for DRM reaction by Li et al. [91]. On the other hand, when Ni nanoparticles are distributed on the external surface of $\mathrm{SiO}_{2}$ support, thermal sintering takes place, causing a Ni particle size increase from ca. $2 \mathrm{~nm}$ for the fresh catalyst to $c a$. $14 \mathrm{~nm}$ after its use for $1400 \mathrm{~min}$ at $700{ }^{\circ} \mathrm{C}$ under DRM conditions [92]. In addition, silica-supported Ni catalysts could also partially loss their specific surface area, (from $68.1 \mathrm{~m}^{2} \mathrm{~g}^{-1}$ to $21.4-59.6 \mathrm{~m}^{2} \mathrm{~g}^{-1}$ ), which affects the catalyst stability during the TRM reaction [42].

\subsection{Magnesia}

Magnesia displays the advantage of having high thermal stability and high basicity $[42,57,84,93]$. However, controversial results have been reported for this support. Despite Song et al. [27] and Tomishige [94] stated that $\mathrm{Ni} / \mathrm{MgO}$ catalysts were highly active for $\mathrm{CH}_{4}$ and $\mathrm{CO}_{2}$ conversion, other studies differed $[57,84,93]$. This could be due to the formation of a NiO-MgO solid solution, requiring particular reduction conditions. At high temperatures, $\mathrm{NiO}$ progressively diffuses into $\mathrm{MgO}$ lattice to form $\mathrm{NiO}-\mathrm{MgO}$ solid solution at any $\mathrm{NiO} / \mathrm{MgO}$ ratio, which is difficult to reduce $[27,57,84]$. This sensitive reduction can take place at high temperatures, resulting in highly-dispersed and active $\mathrm{Ni}(0)$ particles [93]. Therefore, Fedorova et al. [93] used porous nickel ribbons covered with a $\mathrm{MgO}$ underlayer as support to deposit nickel particles by impregnation. After reduction at $900{ }^{\circ} \mathrm{C}$ under $\mathrm{H}_{2}$, highly-dispersed nickel particles (3-5 nm), epitaxially bound to $\mathrm{MgO}$ underlayer were observed. These catalysts exhibited a high activity and stability in TRM (75\% $\mathrm{CH}_{4}$ conversion at $750{ }^{\circ} \mathrm{C}, 1$ bar, $\mathrm{CH}_{4}: \mathrm{CO}_{2}: \mathrm{H}_{2} \mathrm{O}: \mathrm{O}_{2}: \mathrm{N}_{2}=$ 24:18:18:3.5:36.5, flow rate of gas mixture $=25 \mathrm{~L} \mathrm{~h}^{-1}, 0.4 \mathrm{~g}$ of the catalyst).

\subsection{Ceria}

Ceria has also been investigated in TRM reaction given its high thermal stability, high density of basic sites, and high oxygen-storage capacity and mobility $[27,41,51,51,53,56,85]$.

Ohtake et al. [95] demonstrated the high thermal stability of $\mathrm{CeO}_{2}$ synthesized by hydrothermal method. The specific surface area of this support was respectively $139,131,73$ and $50 \mathrm{~m}^{2} \mathrm{~g}^{-1}$ when it was calcined at respectively $400,600,800$ and $900{ }^{\circ} \mathrm{C}$. Thus, even at high temperatures $\left(800-900^{\circ} \mathrm{C}\right)$, usual temperature for methane reforming, this support could maintain a relatively high specific surface area $(>50$ 

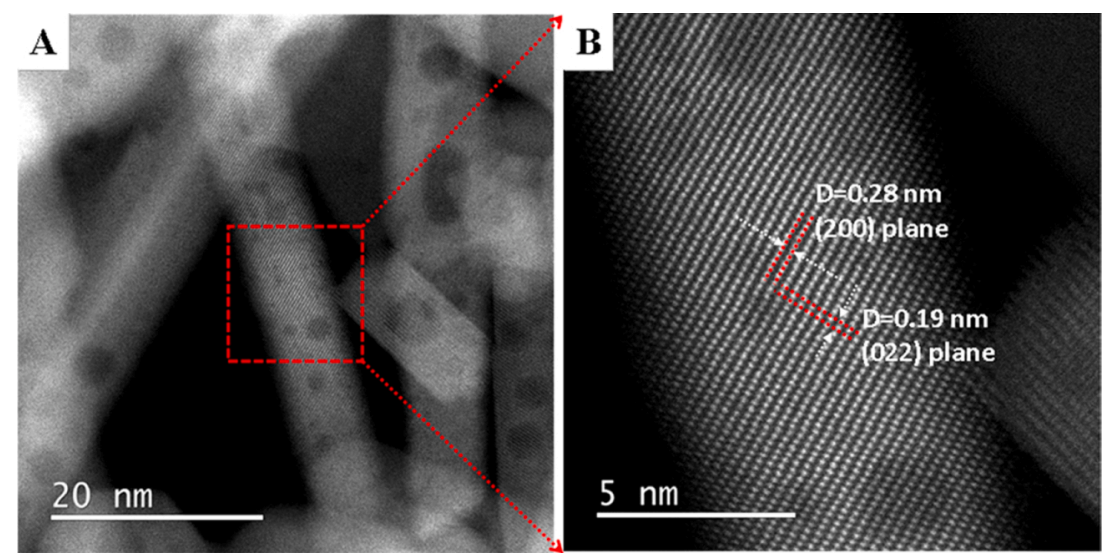

Fig. 8. Aberration-corrected STEM images of $\mathrm{Ni}-\mathrm{Ru} / \mathrm{CeO}_{2} \mathrm{SAC}$ catalyst recovered after DRM reaction at $600{ }^{\circ} \mathrm{C}$, illustrating the absence of nanoparticles on the surface of the support. Reprinted with permission from [74]. Copyright (2019) American Chemical Society.

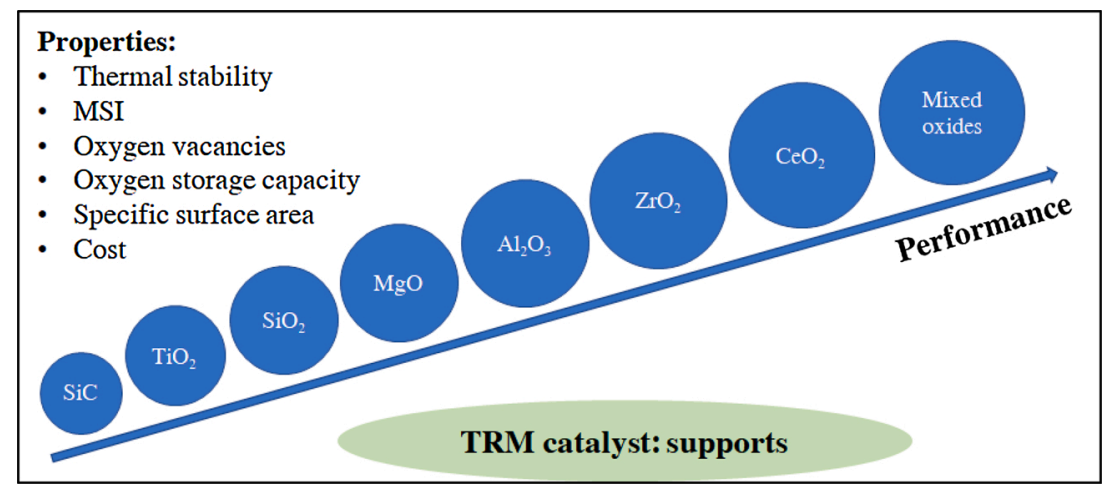

Scheme 2. Illustration of the impact of supports in the design of TRM catalysts.

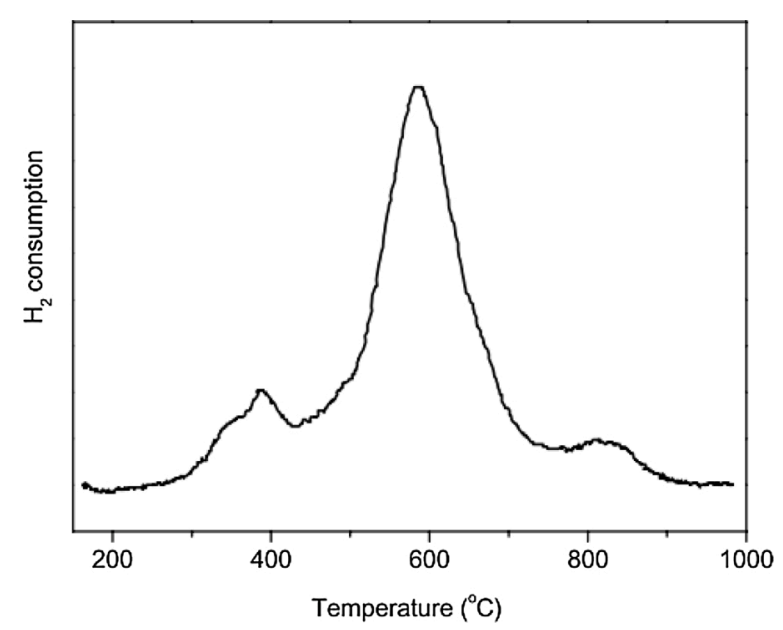

Fig. 9. TPR profile of the $\mathrm{Ni} / \mathrm{Al}_{2} \mathrm{O}_{3}$ catalyst. Reprinted from [81], Copyright (2007), with permission from Elsevier.

$\mathrm{m}^{2} \mathrm{~g}^{-1}$ ). Also, $\mathrm{CeO}_{2}$ is well known by its high redox capacity, promoted by $\mathrm{Ni}$ sites, creating oxygen vacancies in $\mathrm{CeO}_{2}$ lattice, which in turn can stabilize the Ni sites [74]. Moreover, they provide new adsorption sites for $\mathrm{O}_{2}, \mathrm{H}_{2} \mathrm{O}$ and $\mathrm{CO}_{2}$, thus, enhancing coke gasification [27,51,51]. As examples, Lo Faro et al. [51] investigated TRM over $1.75 \mathrm{wt} . \% \mathrm{Ni} / \mathrm{CeO}_{2}$ catalyst. XRD analyses evidenced the insertion of $\mathrm{Ni}(\mathrm{II})$ ions in $\mathrm{CeO}_{2}$ lattice, shifting $\mathrm{CeO}_{2}$ diffraction peaks to higher Bragg angles with respect to pure $\mathrm{CeO}_{2}$. NiO-CeO 2 solid solution was formed, giving oxygen vacancies from its reduction [51]. The formation of $\mathrm{NiO}-\mathrm{CeO}_{2}$ solid solution, and thus oxygen vacancies, is favored by increasing nickel content (range studied: 1.8-31.0 wt\%) [51].

$\mathrm{Ni}$ can also form stronger $\mathrm{O}-\mathrm{Ni}-\mathrm{O}-\mathrm{Ce}-$ bonds in comparison with $\mathrm{Ni}-\mathrm{O}$ bond (in $\mathrm{NiO}$ crystal) by the insertion of $\mathrm{Ni}(\mathrm{II})$ ions in the fluoritetype structure of $\mathrm{CeO}_{2}$ [96]. For that purpose, $\mathrm{CeO}_{2}$ support was prepared by refluxing an aqueous solution of $\left(\mathrm{NH}_{4}\right)_{2} \mathrm{Ce}\left(\mathrm{NO}_{3}\right)_{6}$ at $\mathrm{pH} 9$ using $\left(\mathrm{NH}_{4}\right)_{2} \mathrm{CO}_{3}$ under $500 \mathrm{rpm}$ stirring. The resulting precipitate was finally recovered by centrifugation and dried at $90{ }^{\circ} \mathrm{C}$ for $12 \mathrm{~h}$. Ni deposition $(2.5-10 \mathrm{wt} \%)$ was performed by wet impregnation. The as-prepared $\mathrm{CeO}_{2}$ was added to an aqueous solution of nickel nitrate at $80{ }^{\circ} \mathrm{C}$ and $500 \mathrm{rpm}$. The solvent was eliminated under continuous stirring and the resulting solid was calcined at $500{ }^{\circ} \mathrm{C}$ for $6 \mathrm{~h}$. In the range of Ni loading studied (2.5-10 wt $\%$ ), the catalyst containing more than $2.5 \mathrm{wt} \% \mathrm{Ni}$ led to surface defects through the formation of the $-\mathrm{O}-\mathrm{Ni}-\mathrm{O}-\mathrm{Ce}$ super structure over $\mathrm{CeO}_{2}$ crystal. The high activity and stability of these catalysts in partial methane oxidation into syngas can be explained by the presence of low-coordinated $\mathrm{O}$ atoms [96]. Moreover, the enhanced MSI in $\mathrm{Ni} / \mathrm{CeO}_{2}$ catalysts resulted in small $\mathrm{Ni}$ particles in the reduced catalyst, and thus inducing a high catalytic performance in TRM [51]. In addition, the high density of basic sites in $\mathrm{Ni} / \mathrm{CeO}_{2}$ (as determined by $\mathrm{CO}_{2}$-TPD analysis) enhances $\mathrm{CO}_{2}$ adsorption, which in turn favors coke gasification as highlighted by Pino et al. [53].

\subsection{Zirconia}

Zirconia exhibits the required properties for a support such as: high thermal stability, high ionic conductivity, high mechanical strength, high fracture toughness and hardness [34]. In addition, zirconia is often selected as catalyst support or promoter thanks to the presence of defects on its crystal surface, where oxygen vacancies are easily created. 


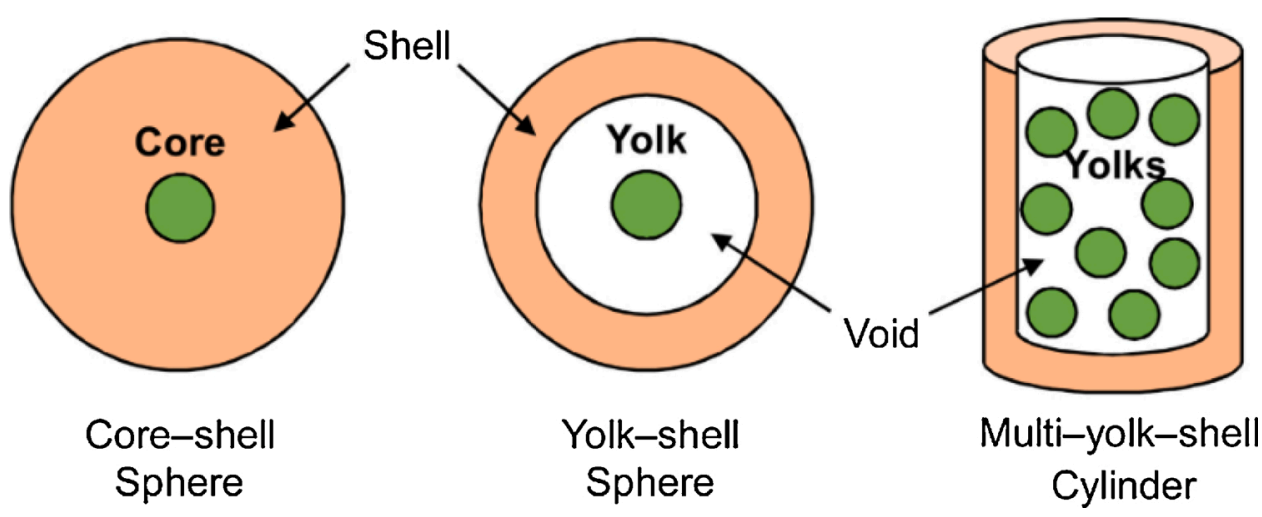

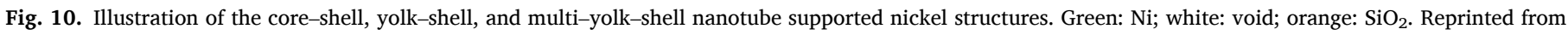

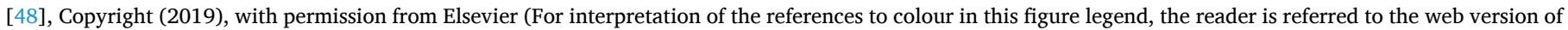
this article.).

Moreover, $\mathrm{ZrO}_{2}$ provides low concentration of Lewis acid sites and a moderate MSI with Ni species [34,59]. $\mathrm{ZrO}_{2}$ and $\mathrm{ZrO}_{2}$-based materials (e.g. yttria-stabilized zirconia - YSZ) have been intensively studied in TRM [34,41,59,56,84,97].

Singha et al. [34] investigated TRM over $\mathrm{Ni} / \mathrm{ZrO}_{2}$ catalysts prepared by hydrothermal method. Average Ni particle size increased with the increase of Ni loading (optimal value being $4.8 \mathrm{wt} \%$ ). High nickel dispersion and strong MSI explained the excellent activity and stability of these catalysts ( $>95 \% \mathrm{CH}_{4}, \mathrm{CO}_{2}$ and $\mathrm{H}_{2} \mathrm{O}$ conversions at $800{ }^{\circ} \mathrm{C}$ without deactivation for more than $100 \mathrm{~h}$ ) [34]. Anchieta et al. [59] prepared a $\mathrm{ZrO}_{2}$ support by precipitation method with the use of an ionic liquid (1-hexadecil-3-metilimidazolium bromide). Then, Ni deposition (5 wt\%) was done by IWI method. In TRM reaction (conditions: $850{ }^{\circ} \mathrm{C}$, molar ratio of $\mathrm{CH}_{4}: \mathrm{CO}_{2}: \mathrm{H}_{2} \mathrm{O}: \mathrm{O}_{2}=1.0: 0.5: 0.5: 0.1$, total gas flow $=185$ $\mathrm{mL} \mathrm{min}{ }^{-1}, \mathrm{GHSV}=45,000 \mathrm{~mL} \mathrm{~g}^{-1} \mathrm{~h}^{-1}$ ), this catalyst, having a specific surface area of $11 \mathrm{~m}^{2} \mathrm{~g}^{-1}$, showed promising catalytic performance with ca. $85 \% \mathrm{CH}_{4}$ conversion while precluding coke deposition. The use of an ionic liquid during support preparation tunes acid-basic properties of the support, and consequently improves the catalytic performance. In fact, under the same conditions of TRM, the catalyst prepared in the absence of the ionic liquid, showing a specific surface area of $17 \mathrm{~m}^{2} \mathrm{~g}^{-1}$, gave only ca. $55 \%$ of $\mathrm{CH}_{4}$ conversion. The catalytic performance of $\mathrm{Ni} / \mathrm{ZrO}_{2}$ could be highly improved by the addition of $\mathrm{Mg}$ playing the role of promoter [97]. In this work, Sun et al. [97] synthesized $\mathrm{Ni} / \mathrm{ZrO}_{2}$ and $\mathrm{Ni} / \mathrm{MgO}-\mathrm{ZrO}_{2}$ by co-precipitation method using nitrate precursors of $\mathrm{Ni}$ (II), $\mathrm{Mg}(\mathrm{II})$ and $\mathrm{Zr}(\mathrm{IV})$, and a $5 \mathrm{wt} \% \mathrm{KOH}$ solution. The precipitate was filtered, dried at $110^{\circ} \mathrm{C}$ for $12 \mathrm{~h}$ and calcined under air at $800^{\circ} \mathrm{C}$ for $4 \mathrm{~h}$. The specific surface areas obtained were 28 and $39 \mathrm{~m}^{2} \mathrm{~g}^{-1}$ for respectively $\mathrm{Ni} / \mathrm{ZrO}_{2}$ and $\mathrm{Ni} / \mathrm{MgO}-\mathrm{ZrO}_{2}$. Under the same conditions in TRM process (reaction conditions: $0.2 \mathrm{~g}$ catalyst, GHSV $=30,000 \mathrm{~mL} \mathrm{~g}^{-1} \mathrm{~h}^{-1}$, molar ratio of $\mathrm{CH}_{4}: \mathrm{CO}_{2}: \mathrm{H}_{2} \mathrm{O}: \mathrm{O}_{2}: \mathrm{N}_{2}=1.0: 0.45: 0.45: 0.1: 0.4,800{ }^{\circ} \mathrm{C}, 1$ bar), $\mathrm{Ni} / \mathrm{MgO}-\mathrm{ZrO}_{2}$ led to $\mathrm{ca}$. $98 \% \mathrm{CH}_{4}$ conversion (exhibiting a good catalyst stability during $58 \mathrm{~h}$ of time-on-stream), while $\mathrm{Ni} / \mathrm{ZrO}_{2}$ showed less than $80 \% \mathrm{CH}_{4}$ conversion. This different catalytic behavior is explained by the presence of $\mathrm{MgO}$, which improved the basicity of the support and stabilized the tetragonal $\mathrm{ZrO}_{2}$ structure.

\subsection{Titania}

Titania is a support largely used in heterogeneous catalysis. It has also been applied in TRM reaction by several authors $[57,84,98]$. The reactivity and stability of $\mathrm{Ni} / \mathrm{TiO}_{2}$ depend on the formation and reduction of $\mathrm{NiTiO}_{3}$ solid solution [57]. The formation of $\mathrm{NiTiO}_{3}$ is favored at high calcination temperature $\left(850{ }^{\circ} \mathrm{C}\right)$, exhibiting a high stability and consequently a reluctance towards reduction [57,84,98]. Moreover, $\mathrm{TiO}_{\mathrm{x}}$ species $(\mathrm{x}<2)$ can be formed, that can migrate onto metallic Ni particles, partially covering them and thus decreasing the Ni dispersion
$[84,98]$. In ethanol reforming, $\mathrm{TiO}_{\mathrm{x}}$ species were able to suppress carbon deposition and to enhance MSI by the formation of new active sites of $\mathrm{Ni}-\mathrm{O}-\mathrm{Ti}^{3+}$ at the boundary between metallic $\mathrm{Ni}$ particles and $\mathrm{TiO}_{2}$ support [99]. For $\mathrm{Ni} / \mathrm{TiO}_{2}$ catalysts applied in the TRM reaction (see Section 2.3 ), low calcination temperature $\left(400{ }^{\circ} \mathrm{C}\right)$ is preferred, leading to moderate MSI and suitable conditions for the reduction of these catalysts [57]. At higher temperature $\left(850^{\circ} \mathrm{C}\right)$, most of $\mathrm{Ni}$ was non-reducible and inactive in TRM [57]. The addition of promoters such as $\mathrm{MgO}$ could also cause a decrease of $\mathrm{Ni}$ reduction degree as revealed by Jiang et al. for $\mathrm{Ni} / \mathrm{Mg}_{\mathrm{x}} \mathrm{Ti}_{1-\mathrm{x}} \mathrm{O}$ catalysts (with $\mathrm{x}=0$ to 1 ) [98]. Without $\mathrm{MgO}$, Ni could completely be reduced under $\mathrm{H}_{2}$ below $650{ }^{\circ} \mathrm{C}$. In the presence of $\mathrm{MgO}$, TPR peak temperatures increased while TPR peak surfaces decreased signifying the increase of non-reducible $\mathrm{Ni}$ [98]. Thus, for $\mathrm{TiO}_{2}$-based nickel supported catalysts, it is strongly recommended to determine the preparation conditions to optimize $\mathrm{Ni}$ reduction by $\mathrm{H}_{2}$ reduction.

\subsection{Mixed oxides}

Mixed oxides allow improving physico-chemical properties required for TRM catalyst supports. $\mathrm{MgO}$ and $\mathrm{CaO}$ with high basicity, $\mathrm{CeO}_{2}$ and $\mathrm{ZrO}_{2}$ with high oxygen storage capacity, and $\mathrm{Y}_{2} \mathrm{O}_{3}$ and $\mathrm{La}_{2} \mathrm{O}_{3}$ with high oxygen lability are particularly targeted in TRM.

$\mathrm{MgAl}_{2} \mathrm{O}_{4}$, a common support used in SRM and DRM, was also investigated in TRM reaction $[40,76,79]$ thanks to its high specific surface area, high thermal sintering resistance and high basicity. Well-dispersed Ni particles formed on $\mathrm{MgAl}_{2} \mathrm{O}_{4}$ surface could be stabilized by SMSI. The presence of $\mathrm{Mg}$ in the spinel structure results in a high basicity, that favors $\mathrm{CO}_{2}$ adsorption and coke gasification [40]. Jiang et al. [98] combined $\mathrm{TiO}_{2}$ with $\mathrm{MgO}$ to obtain $\mathrm{Mg}_{\mathrm{x}} \mathrm{Ti}_{1-\mathrm{x}} \mathrm{O}(\mathrm{x}=0.25 ; 0.5$; 0.75 ) composites. $\mathrm{Ni} / \mathrm{Mg}_{\mathrm{x}} \mathrm{Ti}_{1-\mathrm{x}} \mathrm{O}$ catalysts exhibited similar $\mathrm{Ni}$ dispersion but higher catalytic performance than $\mathrm{Ni} / \mathrm{TiO}_{2}$ and $\mathrm{Ni} / \mathrm{MgO}$. The moderate interaction of $\mathrm{Ni}$ with $\mathrm{Mg}_{\mathrm{x}} \mathrm{Ti}_{1-\mathrm{x}} \mathrm{O}$ support favors both $\mathrm{Ni}$ reducibility and catalyst stability [98]. Walker et al. [35] evaluated the influence of the synthesis methodology on the behavior of $\mathrm{Ni}-\mathrm{MgO}-(\mathrm{Ce}$, $\mathrm{Zr}) \mathrm{O}_{2}$ catalysts under various TRM reaction conditions. The molar ratios of $\mathrm{Ce} / \mathrm{Zr}$ and $\mathrm{Ni} / \mathrm{Mg}$, Ni deposition technique, and Ni content were found as key factors impacting the catalyst performance [35].

Lee et al. investigated $\mathrm{Ni} / \mathrm{CeO}_{2}-\mathrm{ZrO}_{2}-\mathrm{Al}_{2} \mathrm{O}_{3}$ catalysts in methane reforming processes [100]. The supports $\mathrm{CeO}_{2}-\mathrm{ZrO}_{2}-\mathrm{Al}_{2} \mathrm{O}_{3}$ were prepared by IWI method using a commercial $\theta-\mathrm{Al}_{2} \mathrm{O}_{3}$ support $\left(167 \mathrm{~m}^{2} \mathrm{~g}^{-1}\right)$ and solutions of Ce(IV) and Zr(IV) precursors. Ni deposition ( $3 \mathrm{wt} \%$ ) was also performed by IWI method using an aqueous solution of nickel nitrate salt, followed by drying at $100^{\circ} \mathrm{C}$ and air calcination at $550{ }^{\circ} \mathrm{C}$ for 6 h. The resulting catalyst showed very good catalytic performance in TRM at $800{ }^{\circ} \mathrm{C}$ and 3 bar affording 96 and $82 \%$ of respectively $\mathrm{CH}_{4}$ and $\mathrm{CO}_{2}$ conversion.

Si et al. [41] investigated the impact of co-precipitation conditions on 
the performance of $\mathrm{Ni}-\mathrm{CaO}-\mathrm{ZrO}_{2}$ catalysts. As previously mentioned (see Section 2.1.2), working under optimal conditions (10-12 pH, $24 \mathrm{~h}$ reflux time, and calcination at $700{ }^{\circ} \mathrm{C}$ ), led to catalysts with specific surface areas of ca.177-225 $\mathrm{m}^{2} \mathrm{~g}^{-1}$. The corresponding catalysts showed high methane conversion (up to $70 \%$ at $700{ }^{\circ} \mathrm{C}$ and 1 bar; other conditions: $0.3 \mathrm{~g}$ of catalyst; molar ratio of $\mathrm{CH}_{4}: \mathrm{CO}_{2}: \mathrm{O}_{2}: \mathrm{H}_{2} \mathrm{O}=1: 0.5: 0.375: 0.25$; GHSV $=34,000 \mathrm{~mL} \mathrm{~h}^{-1} \mathrm{~g}_{\text {cat }}^{-1}$ ) and good stability (practically no loss of activity during $10 \mathrm{~h}$ of reaction).

La-Ce-O mixed oxide $\left(\mathrm{Ce}_{1-3 \mathrm{x}} \mathrm{La}_{2 \mathrm{x}} \mathrm{Ni}_{\mathrm{x}} \mathrm{O}_{2}, \mathrm{x}=0.10 ; 0.20\right.$; and 0.25) supported Ni catalysts were studied by Pino et al. [54]. Nickel existed under both zero-valent $\mathrm{Ni}$ nanoparticles and cationic Ni(II) inserted in the cubic fluorite structure of $\mathrm{CeO}_{2}$. Despite the low specific surface area of the synthesized catalysts $\left(<4 \mathrm{~m}^{2} \mathrm{~g}^{-1}\right)$, high cationic character of $\mathrm{Ni}$ (II) along with the combination of $\mathrm{Ni}(0)$ in close contact with La-Ce-O matrix resulted in high catalytic activities ( $c a .1 .8 \mathrm{~mol}_{\mathrm{CH} 4} \mathrm{~s}^{-1} \mathrm{~g}_{\mathrm{Ni}}^{-1}$ ) and high catalytic stability while precluding carbon deposition during $6 \mathrm{~h}$ at $800{ }^{\circ} \mathrm{C}$ and atmospheric pressure in TRM process.

Dong et al. [78] tested various Ni-based catalysts supported on complex mixtures of $\mathrm{ZrO}_{2}$ doped with $\mathrm{Y}_{2} \mathrm{O}_{3}$ and another oxide among $\mathrm{CeO}_{2}, \mathrm{MgO}, \mathrm{SiO}_{2}, \mathrm{TiO}_{2}, \mathrm{CaO}$ to distort the crystal lattice of $\mathrm{ZrO}_{2}$. These catalysts were able to overcome coke deposition by facilitating oxygen transfer and increasing oxygen storage and supply. Similar work was conducted by Kang et al. [101] who investigated NiO-YSZ-CeO ${ }_{2}$ catalytic systems, reaching full conversion of $\mathrm{CO}_{2}$ and $\mathrm{CH}_{4}$ above $800{ }^{\circ} \mathrm{C}$.

\subsection{Other supports}

Carbon-based supports and zeolites are largely studied and applied in heterogeneous catalysis, but much less in TRM. To date, Kozonoe et al. [30,102] and Izquierdo et al. [61] seemed to be the first teams who respectively investigated a carbon-based support and a zeolite support (zeolite L) in TRM. MWCNT-supported nickel catalyst, with cerium as promoter, showed very promising catalytic performance (up to $96.8 \%$ of $\mathrm{CH}_{4}$ conversion at $750{ }^{\circ} \mathrm{C}$, and a good stability for $44 \mathrm{~h}$ of reaction) under TRM conditions using a gas mixture of $\mathrm{CH}_{4}: \mathrm{CO}_{2}: \mathrm{H}_{2} \mathrm{O}: \mathrm{O}_{2}: \mathrm{N}_{2}=$ 1:0.34:0.23:0.5:2.1 and space velocity of $1250 \mathrm{~mL} \mathrm{~g}^{-1} \mathrm{~min}^{-1}$ [102]. In the case of the zeolite $\mathrm{L}$, this support was initially stabilized by calcination at $800{ }^{\circ} \mathrm{C}$ before $\mathrm{Ni}$ or $\mathrm{Ni}-\mathrm{Rh}$ deposition. The resulting catalysts showed higher methane conversions and hydrogen yields compared to those obtained with alumina-based catalysts. This catalytic behavior was explained by the high metal dispersions and strong MSI achieved with the zeolite L [61].

Silicon carbide $(\beta-\mathrm{SiC})$ has been largely applied in heterogeneous catalysis during the last decades [103,104]. In TRM, this support was particularly studied by García-Vargas et al. [56,85,105-108]. Ni/ $\beta$-SiC catalysts showed relatively high catalytic activity and stability in TRM, explained by a good Ni dispersion and adequate MSI [61,105-108]. However, $\mathrm{SiC}$ can be irreversibly oxidized into $\mathrm{SiO}_{2}$ by $\mathrm{O}_{2}$ at high temperatures [109].

Hydroxyapatite $\left(\mathrm{Ca}_{10}\left(\mathrm{PO}_{4}\right)_{6}(\mathrm{OH})_{2}\right)$, considered as a relatively-new support in heterogeneous catalysis, has been found as a good catalyst support in DRM [110-117]. A recent work Phan [118] is the first study of hydroxyapatite-based catalysts in TRM with promising results. High methane conversions (up to $90 \%$ ) and particularly high catalytic stability were achieved with $5 \mathrm{wt} / \% \mathrm{Ni} / \mathrm{HA}$ at $800{ }^{\circ} \mathrm{C}$ and $1.6 \mathrm{bar}$ total pressure for $300 \mathrm{~h}$ of reaction (conditions in a fixed bed reactor: $340 \mathrm{mg}$ of catalyst, at $800{ }^{\circ} \mathrm{C}$, molar ratio of $\mathrm{CH}_{4}: \mathrm{CO}_{2}: \mathrm{O}_{2}=1: 0.67: 0.1$ and $\mathrm{S} / \mathrm{C}=$ $0.9, \mathrm{CH}_{4}$ flow rate $=45 \mathrm{~mL} \mathrm{~min}^{-1}$ ).

\subsection{Support comparison and conclusions}

Several studies have compared different supports under the same operating conditions in TRM $[27,57,84,85]$. Song and Pan [27] performed TRM over Ni supported on different supports at $850{ }^{\circ} \mathrm{C}$. The catalytic activity carries on the following trend for $\mathrm{CH}_{4}$ conversion: $\mathrm{Ni} / \mathrm{MgO}>\mathrm{Ni} / \mathrm{MgO}-\mathrm{CeZrO}>\mathrm{Ni} / \mathrm{CeO}_{2} \sim \mathrm{Ni} / \mathrm{ZrO}_{2} \sim \mathrm{Ni} / \mathrm{Al}_{2} \mathrm{O}_{3}>$
$\mathrm{Ni} / \mathrm{CeZrO}$. In another study working at $800^{\circ} \mathrm{C}$, the following trend was

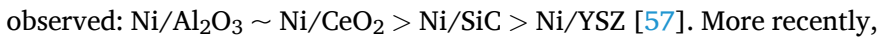
Kumar et al. [57,84] found the following tendency: $\mathrm{Ni} / \mathrm{Al}_{2} \mathrm{O}_{3}>$ $\mathrm{Ni} / \mathrm{SBA}-15>\mathrm{Ni} / \mathrm{ZrO}{ }_{2}>\mathrm{Ni} / \mathrm{CeO}_{2}-\mathrm{ZrO}_{2}>\mathrm{Ni} / \mathrm{TiO}_{2}>\mathrm{Ni} / \mathrm{MgO}$. Song and $\mathrm{Pan}$ [27] showed that $\mathrm{Ni} / \mathrm{MgO}$ was more active than $\mathrm{Ni} / \mathrm{Al}_{2} \mathrm{O}_{3}$, which is in contrast to the results found by Kumar et al. [57,84]. These apparent inconsistencies between different reports must serve to override simplistic comparisons and highlight that catalyst efficiency depends on many parameters such as synthesis methodology, pretreatment conditions, metal particle size, textural and structural properties of supports, etc.

Thus far, most of the conventional supports in heterogeneous catalysis have been investigated in TRM and each of them responds to a greater or lesser extent to the criteria required for TRM catalyst supports. At the current stage of research and development on TRM catalyst, it is difficult to quantitatively compare the different supports studied in this reaction. Nevertheless, we have tried to propose a tentative rating table for the main criteria required for TRM catalyst supports (Table 3). Accordingly, the range of potential impact of each criterion for the design of TRM catalyst is assigned and rated from 1 to 3 (least preferred to most preferred). The total score of the rating serves to compare TRM catalyst supports.

On the basis of the works reported in the literature and the rating in Table 3, Fig. 11 shows the relative comparison of the supports studied in TRM. Among the simple oxides, $\mathrm{ZrO}_{2}$ and $\mathrm{CeO}_{2}$ seem to be the best choices. Mixed oxides offer different possibilities to improve physicochemical and thermal properties. Thus, for future works on TRM, it is recommended to focus on mixed oxides, $\mathrm{CeO}_{2}$ or even $\mathrm{ZrO}_{2}$ to optimize the design of performing TRM catalysts.

\section{Catalyst promoters}

Catalyst performance can be improved by using a promoter. In TRM, the promoters can be classified into two groups: i) s-block elements (alkali and alkaline earth metals) such as $\mathrm{Na}(\mathrm{I}), \mathrm{K}(\mathrm{I}), \mathrm{Ca}(\mathrm{II})$, and $\mathrm{Mg}(\mathrm{II})$; ii) d- and f-block elements such as $\mathrm{Zr}(\mathrm{IV}), \mathrm{La}(\mathrm{III}), \mathrm{Ce}(\mathrm{IV}), \mathrm{Pt}(0)$, and $\mathrm{Rh}$ (0).

\section{1. s-block elements}

Alkali ( $\mathrm{Na}(\mathrm{I}), \mathrm{K}(\mathrm{I})$ ) and alkaline earth ( $\mathrm{Mg}(\mathrm{II}), \mathrm{Ca}(\mathrm{II})$ ) elements have been investigated as promoters of TRM catalysts by different teams [27, $35,97,106,119]$. The addition of $\mathrm{Mg}(\mathrm{II})$ in Ni-based catalysts resulted in a high catalytic activity, stability and could attenuate the coke deposition $[27,120]$. As previously reported in section 3, the reduction of $\mathrm{NiO}-\mathrm{MgO}$ solid solution enhances nickel dispersion and MSI, increases

Table 3

Tentative rating of TRM catalyst supports.

\begin{tabular}{|c|c|c|c|c|}
\hline \multirow{2}{*}{ Criteria } & \multirow{2}{*}{ Indicator } & \multicolumn{3}{|l|}{ Rating } \\
\hline & & 1 & 2 & 3 \\
\hline Thermal stability & $\begin{array}{l}\text { Threshold temperature } \\
\text { for phase/structure } \\
\text { changing }\left({ }^{\circ} \mathrm{C}\right)\end{array}$ & $300-700$ & $700-900$ & $>900$ \\
\hline $\begin{array}{l}\text { Specific surface } \\
\text { area }\end{array}$ & BET $\left(\mathrm{m}^{2} \cdot \mathrm{g}^{-1}\right)$ & $2-10$ & $10-100$ & $>100$ \\
\hline MSI & $\begin{array}{l}\text { Reduction temperature } \\
\left({ }^{\circ} \mathrm{C}\right)\end{array}$ & $300-500$ & $500-700$ & $>700$ \\
\hline Basicity & Density of basic sites (*) & Low & High & $\begin{array}{l}\text { Very } \\
\text { high }\end{array}$ \\
\hline $\begin{array}{l}\text { Oxygen vacancies } \\
\text { and oxygen } \\
\text { storage capacity }\end{array}$ & $\begin{array}{l}\text { Density of oxygen } \\
\text { vacancies and } \\
\text { extractable oxygen from } \\
\text { support }(*)\end{array}$ & Low & High & $\begin{array}{l}\text { Very } \\
\text { high }\end{array}$ \\
\hline Affordable cost & Cost $(*)$ & Expensive & Medium & Cheap \\
\hline
\end{tabular}

(*): To date, data from the literature in TRM reaction are not enough to better rate this criterion. 


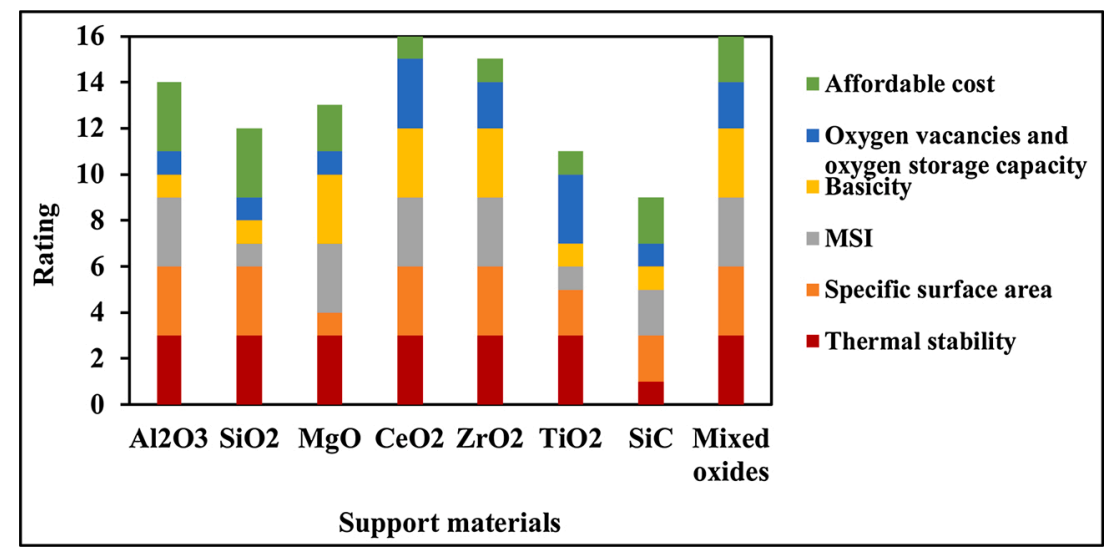

Fig. 11. Relative comparison of TRM catalyst supports on the basis of the nominated criteria, taking into consideration the operation conditions of this process.

basicity, and suppresses carbon deposition, due to the roles of $\mathrm{Mg}$ (II) acting as catalyst promoter $[27,120]$, as reported for different supports in TRM: $\mathrm{Al}_{2} \mathrm{O}_{3}$ [119], $\mathrm{Al}_{2} \mathrm{O}_{3}$-based support [119], $\mathrm{ZrO}_{2}$ [27,97], $\mathrm{CeO}_{2}-\mathrm{ZrO}_{2}$ [27,35], $\beta$-SiC [106], NiMo carbides [121]. Fig. 12 shows an example of the effect of $\mathrm{Mg}(\mathrm{II})$ addition to Ni-CeZrO catalyst [27].

For other alkali and alkaline earth metals, no clear common trend was observed. Orlyk et al. [82] indicated that the addition of $\mathrm{K}_{2} \mathrm{O}$ and $\mathrm{Na}_{2} \mathrm{O}$ to $\mathrm{Ni} / \mathrm{Al}_{2} \mathrm{O}_{3}$ improved $\mathrm{Ni}$ dispersion and thus enhanced catalyst activity. In contrast, García-Vargas et al. [106] pointed out that $\mathrm{Na}(\mathrm{I}), \mathrm{K}$ (I) and $\mathrm{Ca}(\mathrm{II})$ were not useful for $\mathrm{Ni} / \beta$-SiC because they enhanced the oxidation rate of this support into $\mathrm{SiO}_{2}$ during calcination, thus modifying the catalyst structure. Zou et al. [121] indicated that the addition of $\mathrm{K}(\mathrm{I})$ transformed active $\alpha-\mathrm{Al}_{2} \mathrm{O}_{3}$ to less active $\theta-\mathrm{Al}_{2} \mathrm{O}_{3}$. Moreover, for NiMo carbides, the addition of K(I) suppressed the redox ability of this support, thus decreasing the catalytic activity [121].

\section{2. $d$ - and f-block elements}

The addition of $\mathrm{La}_{2} \mathrm{O}_{3}$ or $\mathrm{CeO}_{2}$ to TRM catalysts enhances their catalytic activity by increasing MSI, increasing basicity for $\mathrm{CO}_{2}$ adsorption, and limiting catalytic deactivation by re-oxidation of $\mathrm{Ni}(0)[19,82,53$, 121]. Pino et al. [53] studied the influence of La(III) loading on the performance of $\mathrm{Ni} / \mathrm{CeO}_{2}$ catalyst. By adding $10 \mathrm{wt} . \% \mathrm{La}(\mathrm{III}), \mathrm{CO}_{2}$ and $\mathrm{CH}_{4}$ conversions increased from 93 to $96 \%$ and 83 to $86.5 \%$, respectively, and no carbon deposition was observed (reaction conditions: 800 ${ }^{\circ} \mathrm{C}, 1$ bar, WHSV $=30,000 \mathrm{~h}^{-1}$, molar ratio of $\mathrm{CH}_{4}: \mathrm{CO}_{2}: \mathrm{H}_{2} \mathrm{O}: \mathrm{O}_{2}=$ 1:0.46:0.46:0.1). A further increase in $\mathrm{La}(\mathrm{III})$ loading decreased $\mathrm{CO}_{2}$ and $\mathrm{CH}_{4}$ conversions, while the molar $\mathrm{H}_{2} / \mathrm{CO}$ ratio remained stable at about 1.62-1.65. The strong interaction of $\mathrm{Ni}$ with $\mathrm{La}_{2} \mathrm{O}_{3}$ and surface oxygen

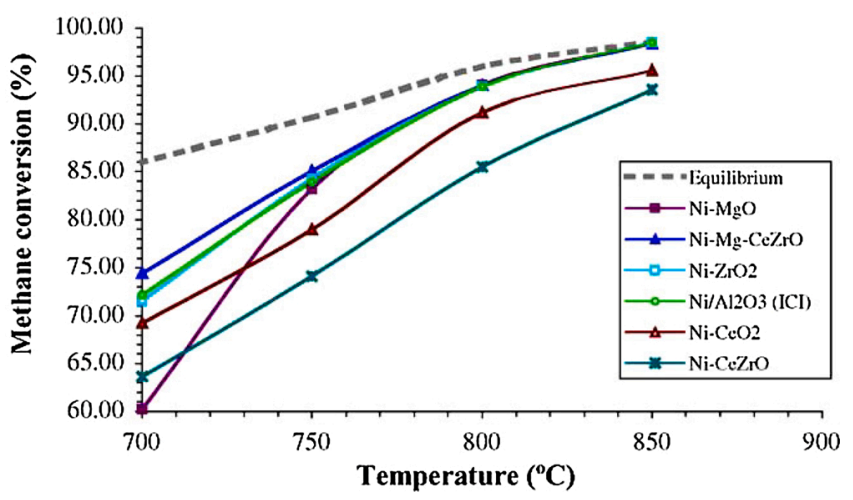

Fig. 12. Example of the effect of $\mathrm{Mg}$ (II) addition to the Ni-CeZrO catalyst in TRM at different reaction temperatures. Reaction conditions: $100 \mathrm{mg}$ catalyst, 1 atm, molar ratio of $\mathrm{CH}_{4}: \mathrm{CO}_{2}: \mathrm{H}_{2} \mathrm{O}: \mathrm{O}_{2}=1: 0.48: 0.54: 0.1\left(\mathrm{CH}_{4}\right.$ flow rate $=25 \mathrm{~mL}$ / min). Reprinted from [27], Copyright (2004), with permission from Elsevier. vacancies of $\mathrm{CeO}_{2}$ improved $\mathrm{Ni}$ dispersion, and induced the formation of $\mathrm{Ce}(\mathrm{III})$ sites, which in turn enhanced catalytic activity. Strong basic sites, created by $\mathrm{La}_{2} \mathrm{O}_{3}$, promoted $\mathrm{CO}_{2}$ adsorption which favored coke elimination. Orlyk et al. [82] and Solov'ev et al. [19] reported that $\mathrm{CeO}_{2}$ and $\mathrm{La}_{2} \mathrm{O}_{3}$ addition avoided catalytic deactivation by providing high O-vacancies for coke gasification and promoting Ni reduction capacity. Zou et al. [121] stated that the addition of La(III) to NiMo carbide prevented Ni particles from sintering, and suppressed carbon deposition, which explains the high catalytic performance of these catalysts. Moreover, $\mathrm{CeO}_{2}$ is reported to be active for catalyst regeneration after sulfur deactivation in TRM [60].

Lino et al. [40] showed the promoter effect of $\mathrm{Ce}-\mathrm{ZrO}_{2}$ addition to $\mathrm{Ni} / \mathrm{MgAl}_{2} \mathrm{O}_{4}$ catalyst in TRM reaction. The conversions of $\mathrm{CH}_{4}$ and $\mathrm{CO}_{2}$ were kept stable at respectively $c a .75$ and $40 \%$ over doped catalyst (reaction conditions: $750{ }^{\circ} \mathrm{C}, 1 \mathrm{bar}, 85 \mathrm{mg}$ of catalyst, molar ratio of $\mathrm{CH}_{4}$ : $\mathrm{CO}_{2}: \mathrm{H}_{2} \mathrm{O}: \mathrm{O}_{2}: \mathrm{N}_{2}=3: 1: 1.4: 0.5: 2, \mathrm{CH}_{4}$ inlet flow rate $=51.5 \mathrm{NmL} \mathrm{min}^{-1}$ ), while non-doped counterpart linearly deactivated during the reaction. This behavior is explained by the adequate basic properties of $\mathrm{Ce}-\mathrm{ZrO}_{2}$, which limits coke formation, and by the favorable effect of $\mathrm{Ce}-\mathrm{ZrO}_{2}$ on $\mathrm{NiO}$ reduction. Especially, when the addition of $\mathrm{Ce}-\mathrm{ZrO}_{2}$ is synergized with $\mathrm{Mg}$ in the $\mathrm{Ni}-\mathrm{Mg} / \mathrm{Ce}-\mathrm{ZrO}_{2} / \mathrm{Al}_{2} \mathrm{O}_{3}$ catalysts, a superior catalytic activity and a high coke resistance were observed by creating new weakly acidic sites, basic sites and redox ability [79,122].

The addition of a small amount $(<0.5 \mathrm{wt} . \%)$ of noble metals such as $\mathrm{Pt}(0)$ or $\mathrm{Rh}(0)$ to Ni-based catalysts limits the catalyst deactivation by $\mathrm{Ni}$ re-oxidation during TRM reaction [123]. In addition, these metals can favor the reduction and the dispersion of the active phase via spill-over effect, and promote surface carbon gasification by providing high surface oxygen species [83,124]. Jiang et al. [123] investigated Pt-modified $\mathrm{Ni} / \mathrm{MgO}$ catalysts. The Ni-Pt alloy formed in these catalysts was active for both methane reforming and methane partial oxidation reactions, leading to different reaction zones inside the catalyst bed (such as auto-thermal zone followed by an oxygen absence zone). The formation of $\mathrm{Ni}$-Pt alloy prevented the re-oxidation of $\mathrm{Ni}(0)$ during TRM reaction.

Izquierdo et al. [83] studied various $\mathrm{Ni}$ - and $\mathrm{Rh}-\mathrm{Ni}$-based catalysts in TRM. The addition of $1 \mathrm{wt}$. $\% \mathrm{Rh}$ to $\mathrm{Ni} / \mathrm{Ce}-\mathrm{Al}_{2} \mathrm{O}_{3}$ catalyst lowered the reduction temperature, which is explained by spillover effect of $\mathrm{Rh}$, and limited the formation of $\mathrm{NiAl}_{2} \mathrm{O}_{4}$, which is reluctant to undergo reduction. In addition, the catalyst showed a high specific surface area of $156.8 \mathrm{~m}^{2} \mathrm{~g}^{-1}$ and a strong MSI (evidenced by the TPR peaks at $751{ }^{\circ} \mathrm{C}$ and $813{ }^{\circ} \mathrm{C}$ ). Consequently, Rh-Ni/Ce- $\mathrm{Al}_{2} \mathrm{O}_{3}$ catalyst exhibited high catalytic performance ( $99.5 \% \mathrm{CH}_{4}$ conversion and $62.8 \% \mathrm{H}_{2}$ yield) in TRM at $800^{\circ} \mathrm{C}$ and $1 \mathrm{~atm}$ (reaction conditions: $340 \mathrm{mg}$ of catalyst; molar ratio of $\mathrm{CO}_{2} / \mathrm{CH}_{4}=0.67, \mathrm{O}_{2} / \mathrm{CH}_{4}=0.25, \mathrm{~S} / \mathrm{C}=1.0$, WHSV $=161 \mathrm{~h}^{-1}$, reaction time of $90 \mathrm{~min}$ ). Similar results on the promoter effect of $\mathrm{Rh}$ were also reported for $\mathrm{Ni}$ /zeolite $\mathrm{L}$ [61]. However, the main drawback of noble metals is their high cost.

On the basis of the rating criteria in Table 3 (except the specific 
surface area which could not be assessed for all promoters), a relative comparison between the two groups of promoters is presented in Fig. 13. Globally, d- and f-block elements, when they are used at low content (e. g. $<0.5 \mathrm{wt} \%$ ), have been found to be more advantageous than s-block elements. Thus, depending on the support used during the catalyst preparation, the presence of a promoter can be envisaged in order to correct drawbacks exhibited by the support (e.g. acidity, metal reducibility etc.).

\section{Conclusions and outlook}

Catalytic TRM is an alternative to SRM, POM and DRM to produce syngas from $\mathrm{CH}_{4}$ using simultaneously $\mathrm{H}_{2} \mathrm{O}, \mathrm{CO}_{2}$, and $\mathrm{O}_{2}$ as oxidants. This review is specifically focused on the development of efficient TRM catalysts, topic intensively investigated during the last two decades. Through this review, the following conclusions and analyses can be inferred:

- Nickel is largely studied as the active metal in TRM. Small Ni nanoparticles, together with a compromise between strong MSI and metal reducibility are recommended. SAC investigation in TRM is also highly suggested for the future work.

- Oxides and mixed oxides are also largely studied as catalyst supports for Ni dispersion in TRM. Particular attention should be paid on the dispersion of the active phase $(\mathrm{Ni})$ and its adequate interaction with the support to tune its reducibility, but also its stability during TRM reaction. Mixed oxides doped with $\mathrm{MgO}, \mathrm{CeO}_{2}, \mathrm{ZrO}_{2}$, and $\mathrm{La}_{2} \mathrm{O}_{3}$ are strongly suggested for future works.

- The use of an appropriate promoter is also highly recommended for improving $\mathrm{Ni}$ reducibility, suppressing coke deposition, and enhancing catalyst stability.

Taking into account the results reported in the literature, the following recommendations can be considered for the future works on catalyst development for TRM:

- The utilization of $\mathrm{Ni}(0)$ as the main active phase: $\mathrm{Ni}$ appears as the best choice to catalyze TRM reaction because of its high efficiency, and its large availability with relative low cost in comparison with classical noble metal catalysts. Small Ni clusters and isolated metal atoms as well as their cooperative effect should be explored in TRM. For that, the development of specific synthesis methods is needed, and the characterization of these species must be carefully conducted.

- The utilization of a noble metal such as Pt at low content ( $<0.5$ wt. $\%)$ as promoter: this favors Ni reduction and solid carbon suppression, and thus enhances catalyst stability.

- The utilization of a spinel such as $\mathrm{MgAl}_{2} \mathrm{O}_{4}$ doped with $\mathrm{CeO}_{2}$ or $\mathrm{ZrO}_{2}$ as catalyst support: alumina-based supports are well known by their high specific surface area and thermal stability in heterogeneous catalysis. The addition of magnesium oxide to form spinel structure enhances the basicity of the alumina support, which is favorable for TRM reaction implying $\mathrm{CO}_{2}$ conversion, while the addition of $\mathrm{CeO}_{2}$ or $\mathrm{ZrO}_{2}$ improves the MSI and provides surface oxygen vacancies which reduces coke formation.

- Scale-up the process: the proof-of-concept of TRM has been demonstrated at laboratory scale but fundamental research towards reaction optimization and validation of the best TRM catalyst hits for each series is currently ongoing. Robust TRM catalyst systems able to operate under optimal conditions are required to enable further studies at large scale to realize and accelerate the deployment of this technological advancement of societal relevance.

\section{CRediT authorship contribution statement}

Huynh Pham Xuan: Data curation, Writing- Original draft

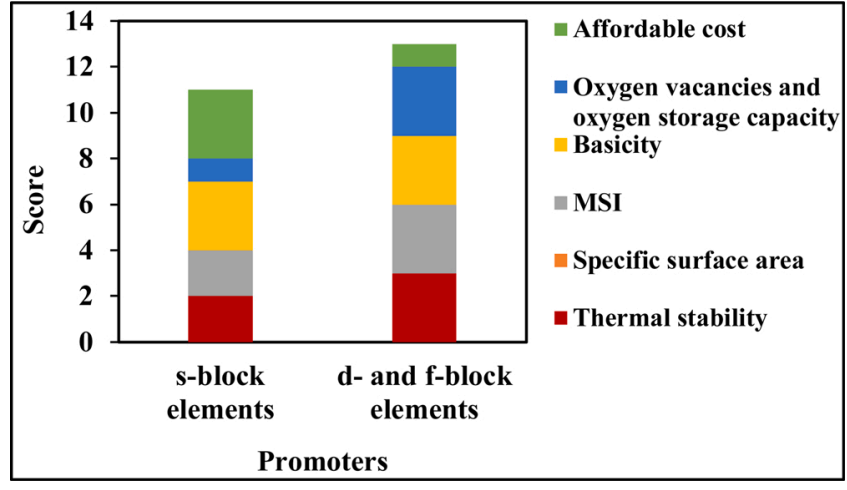

Fig. 13. Relative comparison of TRM catalyst promoters on the basis of the nominated criteria, taking into consideration the operation conditions of this process.

preparation. U.P.M. Ashik: Data curation, Writing- Original draft preparation. Jun-Ichiro Hayashi: Validation, Funding acquisition. Alejandro Pérez Alonso: Data curation, Visualization. Daniel Pla: Supervision, Reviewing, Validation, Funding acquisition. Montserrat Gómez: Supervision, Reviewing, Validation, Funding acquisition. Doan Pham Minh: Conceptualization, Writing- Original draft preparation, Editing, Supervision, Reviewing, Validation, Funding acquisition.

\section{Declaration of Competing Interest}

The authors report no declarations of interest.

\section{Acknowledgments}

Part of this work was financially supported by ANR (France) via CARNOT M.I.N.E.S in the context of the project HyTREND, Occitanie region, and IMT Mines Albi. A. P. A., D. P., and M. G. thank the Université Toulouse 3 - Paul Sabatier and the Centre National de la Recherche Scientifique (CNRS) for their financial support. A. P. A. thanks the Université Fédérale de Toulouse and IMT Mines Albi for his doctoral fellowship. The authors also thank Prof. D.V.N. Vo for technical help.

\section{Appendix A. Supplementary data}

Supplementary material related to this article can be found, in the online version, at doi:https://doi.org/10.1016/j.apcata.2021.118286.

\section{References}

[1] K. Liu, C. Song, V. Subramani, Hydrogen and Syngas Production and Purification Technologies, John Wiley \& Sons, Hoboken, New Jersey, 2009.

[2] https://www.marketsandmarkets.com/ (accessed on May 05, 2021).

[3] Z. Arab Aboosadi, M. Farhadi Yadecoury, Int. J. Chem. React. Eng. 17 (2019), https://doi.org/10.1515/ijcre-2019-0108, 20190108.

[4] S.O. Soloviev, I.V. Gubareni, S.M. Orlyk, Theoretic. Experiment. Chem. 54 (2018) 293-315, https://doi.org/10.1007/s11237-018-9575-5.

[5] A.H. Elbadawi, L. Ge, Z. Li, S. Liu, S. Wang, Z. Zhu, Catal. Rev. (2020), https:// doi.org/10.1080/01614940.2020.1743420.

[6] A.I. Osman, Chem. Eng. Technol. 43 (2020) 641-648, https://doi.org/10.1002/ ceat.201900339.

[7] S. Arora, R. Prasad, RSC Adv. 6 (2016) 108668-108688, https://doi.org/ 10.1039/C6RA20450C.

[8] N.A.K. Aramouni, J.G. Touma, B.A. Tarboush, J. Zeaiter, M.N. Ahmad, Ren. Sust. Ener. Rev. 82 (2018) 2570-2585, https://doi.org/10.1016/j.rser.2017.09.076.

[9] W.J. Jang, J.O. Shim, H.M. Kim, S.Y. Yoo, H.S. Roh, Catal. Today 324 (2019) 15-26, https://doi.org/10.1016/j.cattod.2018.07.032.

[10] B.V.R. Kuncharam, A.G. Dixon, Fuel Process. Technol. 200 (2020), https://doi. org/10.1016/j.fuproc.2019.106314, 106314

[11] R. Ma, B. Xu, X. Zhang, Catal. Today 338 (2019) 18-30, https://doi.org/10.1016/ j.cattod.2019.06.025.

[12] P. Arku, B. Regmi, A. Dutta, Chem. Eng. Res. Des. 136 (2018) 385-402, https:// doi.org/10.1016/j.cherd.2018.05.044. 
[13] G. Kolios, B. Glöckler, A. Gritsch, A. Morillo, G. Eigenberger, Fuel Cells Weinh. (Weinh) 5 (2005) 52-65, https://doi.org/10.1002/fuce.200400065.

[14] U. Hamid, A. Rauf, U. Ahmed, M.S.A.S. Shah, N. Ahmad, Fuel 266 (2020), https://doi.org/10.1016/j.fuel.2020.117111, 117111.

[15] A.Y. Krylova, Solid Fuel Chem. 48 (2014) 22-35, https://doi.org/10.3103/ S0361521914010030.

[16] D.B. Pal, R. Chand, S.N. Upadhyay, P.K. Mishra, Renew. Sustain. Ener. Rev. 93 (2018) 549-565, https://doi.org/10.1016/j.rser.2018.05.003.

[17] A.P. York, T. Xiao, M.L. Green, Topics Catal. 22 (3-4) (2003) 345-358, https:// doi.org/10.1023/A:1023552709642.

[18] A.M. Ranjekar, G.D. Yadav, J. Ind. Chem. Soc. 98 (2021), https://doi.org/ 10.1016/j.jics.2021.100002, 100002.

[19] S.A. Solov'ev, Y.V. Gubareni, Y.P. Kurilets, S.N. Orlik, Theor. Exp. Chem. 48 (2012) 199-205, https://doi.org/10.1007/s11237-012-9262-x.

[20] S. Jain, D. Newman, A. Nzihou, H. Dekker, P. Le Feuvre, H. Richter, F. Gobe, C. Morton, R. Thompson, Global Potential of Biogas, World biogas association, 2019.

[21] C.S. Song, Chem. Innov. 31 (2001) 21-26.

[22] K. Świrk, T. Grzybek, M. Motak, Tri-reforming as a process of $\mathrm{CO} 2$ utilization and a novel concept of energy storage in chemical products, E3S Web of Conferences 14 (2017), https://doi.org/10.1051/e3sconf/20171402038, 02038.

[23] K. Świrk, J. Grams, M. Motak, P. Da Costa, T. Grzybek, J. CO2 Utiliz. 42 (2020), https://doi.org/10.1016/j.jcou.2020.101317, 101317.

[24] Z. Li, Z. Wang, S. Kawi, ChemCatChem 11 (2019) 202-224, https://doi.org/ 10.1002/cctc.201801266.

[25] Q. Wei, X. Gao, L. Wang, Q. Ma, Fuel 27 (2020), https://doi.org/10.1016/j. fuel.2020.117631, 117631.

[26] N. Gao, M. Cheng, C. Quan, Y. Zheng, Fuel 27 (2020), https://doi.org/10.1016/j fuel.2020.117702, 117702 .

[27] C. Song, W. Pan, Catal. Today 98 (2004) 463-484, https://doi.org/10.1016/j cattod.2004.09.054.

[28] L.J.L. Maciel, E.A.M. de Souza, V.O. Cavalcanti-Filho, A. Knoechelmann, C.A. M. de Abreu, React. Kinet. Mech. Catal. 101 (2010) 407-416, https://doi.org/ 10.1007/s11144-010-0232-9.

[29] R. Kumar, K.K. Pant, Appl. Surf. Sci. 515 (2020), https://doi.org/10.1016/j. apsusc.2020.146010, 146010

[30] C.E. Kozonoe, R. de Paiva Floro Bonfim, R.M.B. Alves, M. Schmal, Fuel 256 (2019), https://doi.org/10.1016/j.fuel.2019.115917, 115917.

[31] D.J. Moon, Catal. Surv. Asia 12 (2008) 188-202, https://doi.org/10.1007/ s10563-008-9051-7.

[32] X. Zhao, B. Joseph, J. Kuhn, S. Ozcan, iScience 23 (2020), https://doi.org/ 10.1016/j.isci.2020.101082, 101082.

[33] D. Pham Minh, H. Pham Xuan, T.J. Siang, D.V.N. Vo, Appl. Catal. A Gen. 621 (2021), https://doi.org/10.1016/j.apcata.2021.118202, 118202.

[34] R.K. Singha, A. Shukla, A. Yadav, S. Adak, Z. Iqbal, N. Siddiqui, R. Bal, Appl. Energy 178 (2016) 110-125, https://doi.org/10.1016/j.apenergy.2016.06.043.

[35] D.M. Walker, S.L. Pettit, J.T. Wolan, J.N. Kuhn, Appl. Catal. A Gen. 445-446 (2012) 61-68, https://doi.org/10.1016/j.apcata.2012.08.015.

[36] U.P.M. Ashik, S. Asano, S. Kudo, D. Pham Minh, S. Appari, E. Hisahiro, J. I. Hayashi, Catalysts 10 (2020) 21, https://doi.org/10.3390/catal10010021.

[37] J.R.A. Sietsma, A. Jos van Dillen, P.E. de Jongh, K.P. de Jong, Application of ordered mesoporous materials as model supports to study catalyst preparation by impregnation and drying, in: E.M. Gaigneaux, M. Devillers, D.E. de Vos, S. Hermans, P.A. Jacobs, J.A. Martens, P. Ruiz (Eds.), Scientific Bases for the Preparation of Heterogeneous Catalysts, 162, Elsevier, Amsterdam, 2006, pp. 95-102.

[38] R. Raudaskoski, E. Turpeinen, R. Lenkkeri, E. Pongrácz, R.L. Keiski, Catal. Today 144 (2009) 318-323, https://doi.org/10.1016/j.cattod.2008.11.026.

[39] T. Horiuchi, K. Sakuma, T. Fukui, Y. Kubo, T. Osaki, T. Mori, Appl. Catal. A Gen. 144 (1996) 111-120, https://doi.org/10.1016/0926-860X(96)00100-7.

[40] A.V.P. Lino, E.M. Assaf, J.M. Assaf, J. CO2 Util. 33 (2019) 273-283, https://doi. org/10.1016/j.jcou.2019.06.016.

[41] L.J. Si, C.Z. Wang, N.N. Sun, X. Wen, N. Zhao, F.K. Xiao, W. Wei, Y.H. Sun, J. Fuel Chem. Technol. 40 (2012) 210-215, https://doi.org/10.1016/s1872-5813(12 60011-5.

[42] A.J. Majewski, J. Wood, Int. J. Hydr. Ener. 39 (2014) 12578-12585, https://doi. org/10.1016/j.ijhydene.2014.06.071.

[43] G. Huang, C.H. Lu, H.H. Yang, in: X. Wang, X. Chen (Eds.), Novel Nanomaterials for Biomedical, Environmental and Energy Applications, Elsevier, Amsterdam, 2019, pp. 89-109.

[44] H. Zhong, T. Mirkovic, G.D. Scholes, in: D.L. Andrews, G.D. Scholes, G. P. Wiederrecht (Eds.), Comprehensive Nanoscience and Technology, Academic Press, Amsterdam, 2011, pp. 153-201.

[45] R.K. Singha, S. Das, M. Pandey, S. Kumar, R. Bal, A. Bordoloi, Catal. Sci. Technol. 6 (2016) 7122-7136, https://doi.org/10.1039/C5CY01323B.

[46] S. Das, S. Thakur, A. Bag, M.S. Gupta, P. Mondal, A. Bordoloi, J. Catal. 330 (2015) 46-60, https://doi.org/10.1016/j.jcat.2015.06.010.

[47] E. McEvoy, S. Donegan, J. Power, K. Altria, A. Marsh, in: I.D. Wilson (Ed.), Encyclopedia of Separation Science, Academic Press, Oxford, 2007, pp. 1-10.

[48] S. Kim, B.S. Crandall, M.J. Lance, N. Cordonnier, J. Lauterbach, E. Sasmaz, Appl. Catal. B: Env. 259 (2019), https://doi.org/10.1016/j.apcatb.2019.118037, 118037.

[49] B. Safavinia, Y. Wang, C. Jiang, C. Roman, P. Darapaneni, J. Larriviere, D. A. Cullen, K.M. Dooley, J.A. Dorman, ACS Catal. 10 (2020) 4070-4079, https:// doi.org/10.1021/acscatal.0c00203.
[50] M. Usman, W.M.A. Wan Daud, RSC Adv. 6 (2016) 38277-38289, https://doi.org/ 10.1039/C6RA01652A.

[51] A. Vita, L. Pino, F. Cipitì, M. Laganà, V. Recupero, Fuel Proc. Technol. 127 (2014) 47-58, https://doi.org/10.1016/j.fuproc.2014.06.014.

[52] M. Lo Faro, A. Vita, L. Pino, A.S. Aricò, Fuel Proc. Technol. 115 (2013) 238-245, https://doi.org/10.1016/j.fuproc.2013.06.008

[53] L. Pino, A. Vita, F. Cipitì, M. Laganà, V. Recupero, Appl. Catal. B: Env. 104 (2011) 64-73, https://doi.org/10.1016/j.apcatb.2011.02.027.

[54] L. Pino, A. Vita, M. Laganà, V. Recupero, Appl. Catal. B Env. 148-149 (2014) 91-105, https://doi.org/10.1016/j.apcatb.2013.10.043.

[55] K.T. de C. Roseno, R.A. Antunes, R.M.B. Alves, M. Schmal, Catal. Lett. (2021), https://doi.org/10.1007/s10562-021-03600-0.

[56] J.M. García-Vargas, J.L. Valverde, A. de Lucas-Consuegra, B. Gómez-Monedero, P. Sánchez, F. Dorado, Appl. Catal. A Gen. 431-432 (2012) 49-56, https://doi. org/10.1016/j.apcata.2012.04.016.

[57] R. Kumar, K. Kumar, K.K. Pant, N.V. Choudary, Int. J. Hydr. Ener. 45 (2019) 1911-1929, https://doi.org/10.1016/j.ijhydene.2019.11.111.

[58] D. Pham Minh, T.J. Siang, D.V.N. Vo, T.S. Phan, C. Ridart, A. Nzihou, D. Grouset, Chapter 4 - Hydrogen production from biogas reforming: An overview of steam reforming, dry reforming, dual reforming, and tri-reforming of methane. "Hydrogen Supply Chains - Design, Deployment and Operation", Academic Press, 2018, pp. 111-166, https://doi.org/10.1016/B978-0-12-811197-0.00004-X.

[59] C.G. Anchieta, E.M. Assaf, J.M. Assaf, Int. J. Hydr. Ener. 44 (2019) 9316-9327, https://doi.org/10.1016/j.ijhydene.2019.02.122.

[60] U. Izquierdo, I. García-García, A.M. Gutierrez, J.R. Arraibi, V.L. Barrio, J. F. Cambra, P.L. Arias, Catalysts 8 (2018) 12, https://doi.org/10.3390/ catal8010012.

[61] U. Izquierdo, V.L. Barrio, K. Bizkarra, A.M. Gutierrez, J.R. Arraibi, L. Gartzia, J. Bañuelos, I. Lopez-Arbeloa, J.F. Cambra, Chem. Eng. J. 238 (2014) 178-188, https://doi.org/10.1016/j.cej.2013.08.093.

[62] R.K. Singha, A. Yadav, A. Agrawal, A. Shukla, S. Adak, T. Sasaki, R. Bal, Appl. Catal. B: Env. 191 (2016) 165-178, https://doi.org/10.1016/j. apcatb. 2016.03.029.

[63] S. Zhang, S. Muratsugu, N. Ishiguro, M. Tada, ACS Catal. 3 (2013) 1855-1864, https://doi.org/10.1021/cs400159w.

[64] V.A. Kondratenko, C. Berger-Karin, E.V. Kondratenko, ACS Catal. 4 (2014) 3136-3144, https://doi.org/10.1021/cs5002465.

[65] L. Pino, A. Vita, C. Italiano, C. Fabiano, M. Lagana, V. Recupero, Adv. Sci. Technol. 93 (2014) 19-24, https://doi.org/10.4028/www.scientific.net/ AST.93.19.

[66] X. Yang, A. Wang, B. Qiao, J. Li, T. Zhang, Acc. Chem. Res. 46 (2013) 1740-1748, https://doi.org/10.1021/ar300361m.

[67] F. Chen, X. Jiang, L. Zhang, R. Lang, B. Qiao, Chinese J. Catal. 39 (2018) 893-898, https://doi.org/10.1016/S1872-2067(18)63047-5.

[68] N. Cheng, L. Zhang, K. Doyle-Davis, X. Sun, Electrochem. Ener. Rev. 2 (2019) 539-573, https://doi.org/10.1007/s41918-019-00050-6.

[69] Y.H. Hu, Catal. Today 148 (2009) 206-211, https://doi.org/10.1016/j. cattod.2009.07.076.

[70] S. Tang, L. Ji, J. Lin, H.C. Zeng, K.L. Tan, K. Li, J. Catal. 194 (2000) 424-430, https://doi.org/10.1006/jcat.2000.2957.

[71] M. Akri, S. Zhao, X. Li, K. Zang, A.F. Lee, M.A. Isaacs, W. Xi, Y. Gangarajula, J. Luo, Y. Ren, Y.T. Cui, L. Li, Y. Su, X. Pan, W. Wen, Y. Pan, K. Wilson, L. Li, B. Qiao, H. Ishii, Y.F. Liao, A. Wang, X. Wang, T. Zhang, Nat. Commun. 10 (2019) 1-10, https://doi.org/10.1038/s41467-019-12843-w.

[72] Z. Zuo, S. Liu, Z. Wang, C. Liu, W. Huang, J. Huang, P. Liu, ACS Catal. 8 (2018) 9821-9835, https://doi.org/10.1021/acscatal.8b02277.

[73] M. Akri, A. El Kasmi, C. Batiot-Dupeyrat, B. Qiao, Catalysts 10 (2020) 630, https://doi.org/10.3390/catal10060630.

[74] Y. Tang, Y. Wei, Z. Wang, S. Zhang, Y. Li, L. Nguyen, Y. Li, Y. Zhou, W. Shen, F. F. Tao, P. Hu, J. Am. Chem. Soc. 141 (2019) 7283-7293, https://doi.org/ 10.1021/jacs.8b10910.

[75] P. Serp, Nanoscale 13 (2021) 5985-6004, https://doi.org/10.1039/ D1NR00465D.

[76] A.V.P. Lino, Y.N. Colmenares Calderon, V.R. Mastelaro, E.M. Assaf, J.M. Assaf, Appl. Surf. Sci. 481 (2019) 747-760, https://doi.org/10.1016/j. apsusc. 2019.03.140.

[77] I. Sebai, A. Boulahaouache, M. Trari, N. Salhi, Int. J. Hydr. Ener. 44 (2019) 9949-9958, https://doi.org/10.1016/j.ijhydene.2018.12.050.

[78] D.J. Moon, J.S. Kang, W. S. Nho, D.H. Kim, S. D. Lee, B. G. Lee, Ni-based catalyst for Tri-reforming of methane and its catalysis application for the production of syngas, US patent: US20080260628A1 (2008).

[79] X. Zhao, D.M. Walker, D. Maiti, A.D. Petrov, M. Kastelic, B. Joseph, J.N. Kuhn, Ind. Eng. Chem. Res. 57 (2018) 845-855, https://doi.org/10.1021/acs. iecr.7b03669.

[80] J. Yoo, Y. Bang, S.J. Han, S. Park, J.H. Song, I.H. Song, J. Mol. Catal. A Chem. 410 (2015) 74-80, https://doi.org/10.1016/j.molcata.2015.09.008.

[81] H.T. Jiang, H.Q. Li, Y. Zhang, J. Fuel Chem. Technol. 35 (2007) 72-78, https:// doi.org/10.1016/S1872-5813(07)60012-7.

[82] S.N. Orlyk, M.R. Kantserova, T.K. Shashkova, E.V. Gubareni, V.I. Chedryk, S. A. Soloviev, Theor. Exp. Chem. 49 (2013) 22-34, https://doi.org/10.1007/ s11237-013-9290-1.

[83] U. Izquierdo, V.L. Barrio, J. Requies, J.F. Cambra, M.B. Güemez, P.L. Arias, Int. J. Hydr. Ener. 38 (2013) 7623-7631, https://doi.org/10.1016/j. ijhydene.2012.09.107.

[84] R. Kumar, K. Kumar, N.V. Choudary, K.K. Pant, Fuel Proc. Technol. 186 (2019) 40-52, https://doi.org/10.1016/j.fuproc.2018.12.018. 
[85] J.M. García-Vargas, J.L. Valverde, F. Dorado, P. Sánchez, J. Mol. Catal. A Chem. 395 (2014) 108-116, https://doi.org/10.1016/j.molcata.2014.08.019.

[86] J. Du, J. Gao, F. Gu, J. Zhuang, B. Lu, L. Jia, G. Xu, Q. Liu, F. Su, Int. J. Hydr. Ener. 43 (2018) 20661-20670, https://doi.org/10.1016/j.ijhydene.2018.09.128.

[87] J.R.H. Ross, M.C.F. Steel, A. Zeini-Isfahani, J. Catal. 52 (1978) 280-290, https:// doi.org/10.1016/0021-9517(78)90142-2.

[88] D. Sun, X. Li, S. Ji, L. Cao, J. Nat. Gas Chem. 19 (2010) 369-374, https://doi.org/ 10.1016/S1003-9953(09)60096-7.

[89] W. Cai, L. Ye, L. Zhang, Y. Ren, B. Yue, X. Chen, H. He, Materials 7 (2014) 2340-2355, https://doi.org/10.3390/ma7032340.

[90] X.Y. Quek, D. Liu, W.N.E. Cheo, H. Wang, Y. Chen, Y. Yang, Appl. Catal. B: Env. 95 (2010) 374-382, https://doi.org/10.1016/j. apcatb. 2010.01.016.

[91] Z. Li, Z. Wang, B. Jianga, S. Kawi, Catal. Sci. Technol. 8 (2018) 3363-3371, https://doi.org/10.1039/C8CY00767E.

[92] V.G. de la Cruz-Flores, A. Martinez-Hernandez, M.A. Gracia-Pinilla, Appl. Catal. A Gen. 594 (2020), https://doi.org/10.1016/j.apcata.2020.117455, 117455.

[93] Z.A. Fedorova, M.M. Danilova, V.I. Zaikovskii, T.A. Krieger, Mater. Lett. 263 (2020), https://doi.org/10.1016/j.matlet.2019.127156, 127156.

[94] K. Tomishige, Catal. Today 89 (2004) 405-418, https://doi.org/10.1016/j. cattod.2004.01.003.

[95] N. Ohtake, M. Katoh, S. Sugiyama, J. Ceram. Soc. Japan 125 (2017) 57-61, https://doi.org/10.2109/jcersj2.16255.

[96] P. Pal, R.K. Singha, A. Saha, R. Bal, A.B. Panda, J. Phys. Chem. C 119 (2015) 13610-13680, https://doi.org/10.1021/acs.jpcc.5b01724.

[97] L.Z. Sun, Y.S. Tan, Q.D. Zhang, H.J. Xie, Y.Z. Han, J. Fuel Chem. Technol. 40 (2012) 831-837, https://doi.org/10.1016/s1872-5813(12)60032-2.

[98] H. Jiang, H. Li, H. Xu, Y. Zhang, Fuel Proc. Technol. 88 (2007) 988-995, https:// doi.org/10.1016/j.fuproc.2007.05.007.

[99] J.L. Ye, Y.Q. Wang, Y. Liu, H. Wang, Int. J. Hydr. Ener. 33 (2008) 6602-6611, https://doi.org/10.1016/j.ijhydene.2008.08.036.

[100] S.H. Lee, W. Cho, W.S. Ju, B.H. Cho, Y.C. Lee, Y.S. Baek, Catal. Today 87 (2003) 133-137, https://doi.org/10.1016/j.cattod.2003.10.005.

[101] J.S. Kang, D.H. Kim, S.D. Lee, S.I. Hong, D.J. Moon, Appl. Catal. A Gen. 332 (2007) 153-158, https://doi.org/10.1016/j.apcata.2007.08.017.

[102] C.E. Kozonoe, R.M.B. Alvesa, M. Schmal, Fuel 281 (2020), https://doi.org/ 10.1016/j.fuel.2020.118749, 118749.

[103] M.J. Ledoux, C. Pham-Huu, CATTECH 5 (2011) 226-246, https://doi.org/ 10.1023/A:1014092930183.

[104] A. Majid, N. Rani, M.F. Malik, N. Ahmad, N.A. Hassan, F. Hussain, A. Shakoor, Ceram. Int. 45 (2019) 8069-8080, https://doi.org/10.1016/j. ceramint.2019.01.167.

[105] J.M. García-Vargas, J.L. Valverde, J. Díez, F. Dorado, P. Sánchez, Int. J. Hydr Ener. 40 (2015) 8677-8687, https://doi.org/10.1016/j.ijhydene.2015.05.032.

[106] J.M. García-Vargas, J.L. Valverde, J. Díez, P. Sánchez, F. Dorado, Appl. Catal. B Env. 148-149 (2014) 322-329, https://doi.org/10.1016/j.apcatb.2013.11.013.
[107] J.M. García-Vargas, J.L. Valverde, A. de Lucas-Consuegra, B. Gómez-Monedero, F. Dorado, P. Sánchez, Int. J. Hydr. Ener. 38 (2013) 4524-4532, https://doi.org/ 10.1016/j.ijhydene.2013.02.001.

[108] J.M. García-Vargas, J.L. Valverde, J. Díez, P. Sánchez, F. Dorado, Appl. Catal. B: Env. 164 (2015) 316-323, https://doi.org/10.1016/j.apcatb.2014.09.044.

[109] A.R. Sane, P.M. Nigay, D. Pham Minh, C. Toussaint, A. Germeau, N. Semlal, R. Boulif, A. Nzihou, J. Therm. Anal. Calorim. 140 (2020) 2087-2096, https:// doi.org/10.1007/s10973-019-08964-5.

[110] Z. Boukha, M. Kacimi, M.F.R. Pereira, J.L. Faria, J.L. Figueiredo, M. Ziyad, Appl. Catal. A Gen. 317 (2007) 299-309, https://doi.org/10.1016/j apcata.2006.10.029.

[111] T.S. Phan, A.R. Sane, B. Rêgo de Vasconcelos, A. Nzihou, P. Sharrock, D. Grouset, D. Pham Minh, Appl. Catal. B: Env. 224 (2018) 310-321, https://doi.org/ 10.1016/j.apcatb.2017.10.063.

[112] B. Rêgo de Vasconcelos, D. Pham Minh, N. Lyczko, T.S. Phan, P. Sharrock, A. Nzihou, Fuel 226 (2018) 195-203, https://doi.org/10.1016/j. fuel.2018.04.017.

[113] B. Rêgo de Vasconcelos, D. Pham Minh, P. Sharrock, A. Nzihou, Catal. Today 310 (2018) 107-115, https://doi.org/10.1016/j.cattod.2017.05.092.

[114] B. Rêgo de Vasconcelos, D. Pham Minh, E. Martins, A. Germeau, P. Sharrock, A. Nzihou, Int. J. Hydr. Ener. 45 (2020) 18502-18518, https://doi.org/10.1016/ j.ijhydene.2019.08.068.

[115] B. Rêgo de Vasconcelos, D. Pham Minh, E. Martins, A. Germeau, P. Sharrock, A. Nzihou, Chem. Eng. Technol. 43 (4) (2020) 698-704, https://doi.org/ 10.1002/ceat.201900461.

[116] T.Q. Tran, D. Pham Minh, T.S. Phan, Q.N. Pham, H. Nguyen Xuan, Chem. Eng. Sci. (2020), https://doi.org/10.1016/j.ces.2020.115975.

[117] Z. Boukha, M.P. Yeste, M.A. Cauqui, J.R. González-Velasco, Appl. Catal. A Gen. 580 (2019) 34-45, https://doi.org/10.1016/j.apcata.2019.04.034.

[118] T.S. Phan, Élaboration, caractérisation et mise en oeuvre d'un catalyseur dans le reformage du biogaz en vue de la production de l'hydrogène vert, $\mathrm{PhD}$ thesis, IMT Mines, Albi, 2020. http://theses.fr/s164217.

[119] X. Zhao, H.T. Ngo, D.M. Walker, D. Weber, D. Maiti, U. Cimenler, A.D. Petrov, B. Joseph, J.N. Kuhn, Chem. Eng. Commun. 205 (2018) 1129-1142, https://doi. org/10.1080/00986445.2018.1434162.

[120] G. Nahar, D. Mote, V. Dupon, Renew. Sust. Ener. Rev. 76 (2017) 1032-1052, https://doi.org/10.1016/j.rser.2017.02.031.

[121] H. Zou, S. Chen, J. Huang, Z. Zhao, Int. J. Hydr. Ener. 41 (2016) 16842-16850, https://doi.org/10.1016/j.ijhydene.2016.07.108.

[122] W. Cho, T. Song, A. Mitsos, J.T. McKinnon, G.H. Ko, J.E. Tolsma, D. Denholm, T. Park, Catal. Today 139 (2009) 261-267, https://doi.org/10.1016/j. cattod.2008.04.051.

[123] H. Jiang, H. Li, H. Fan, Appl. Mech. Mater. 252 (2013) 255-258, https://doi.org/ 10.4028/www scientific net/AMM.252.255.

[124] D. Pham Minh, T.J. Siang, N.D.V. Vo, T.S. Phan, A. Nzihou, D. Grouset, in: C. Azzaro-Pantel (Ed.), Hydrogen Supply Chains Design, Deployment and Operation, Academic Press, London, 2019, pp. 111-166. 